\title{
Simulation of the effects of low volatility organic compounds on aerosol number concentrations in Europe
}

${ }^{[1]}$ Department of Chemical Engineering, University of Patras, Patras, Greece

${ }^{[2]}$ Institute of Chemical Engineering Sciences, Foundation for Research and Technology - Hellas (FORTH/ICE-HT), Patras, Greece

Abstract

PMCAMx-UF, a three-dimensional chemical transport model focusing on the simulation of the ultrafine particle size distribution and composition has been extended with the addition of reactions of chemical aging of semi-volatile anthropogenic organic vapors, the emissions and chemical aging by intermediate volatile organic compounds (IVOCs) and the production of extremely low volatility organic compounds (ELVOCs) by monoterpenes. The model is applied in Europe to quantify the effect of these processes on particle number concentrations. The model predictions are evaluated against both ground measurements collected during the PEGASOS 2012 summer campaign across many stations in Europe and airborne observations by a Zeppelin measuring above Po-Valley, Italy. PMCAMx-UF reproduces the ground level daily average concentrations of particles larger than $100 \mathrm{~nm}\left(N_{100}\right)$ with normalized mean error (NME) of $45 \%$ and normalized mean bias (NMB) close to $10 \%$. For the same simulation, PMCAMx-UF tends to overestimate the concentration of particles larger than $10 \mathrm{~nm}\left(N_{10}\right)$ with a daily NMB of $23 \%$ and a daily NME of $63 \%$. The model was able to reproduce more than $75 \%$ of the $N_{10}$ and $N_{100}$ airborne observations (Zeppelin) within a factor of 2 .

The ELVOC production by monoterpenes is predicted to lead to surprisingly small changes of the average number concentrations over Europe. The total number concentration decreased due to the ELVOC formation by $0.2 \%$, the $N_{10}$ decreases by $1.1 \%$, while $N_{50}$ increased by $3 \%$ and $N_{100}$ by $4 \%$ due to this new SOA source. This small change is due to the nonlinearity of the system with increases predicted in some areas and decreases in others, but also the cancelation of the effects of the various processes like accelerated growth and accelerated coagulation. Locally, the effects can 
be significant. For example, an increase in $N_{100}$ by $20-50 \%$ is predicted over Scandinavia and significant increases (10-20\%) over some parts of central Europe. The ELVOCs contributed on average around $0.5 \mu \mathrm{g} \mathrm{m}^{-3}$ and accounted for $10-15 \%$ of the $\mathrm{PM}_{2.5} \mathrm{OA}$. The addition of IVOC emissions and their aging reactions led to surprising reduction of the total number of particles $\left(N_{t o t}\right)$ and $N_{10}$ by $10-15$ and 5-10\%, respectively, and to an increase of the concentration of $N_{100}$ by 5$10 \%$. These were due to the accelerated coagulation and reduced nucleation rates.

\section{Introduction}

Two major processes are responsible for the introduction of new particles in the atmosphere: direct emission from numerous sources and nucleation from low-volatility vapors. New particles formed by nucleation can either grow by condensation of vapors (e.g. sulfuric acid, ammonia, nitric acid, and organics) to larger sizes becoming cloud condensation nuclei (CCN) and thereby increasing the cloud droplet number concentration (CDNC) or affected by coagulation with pre-existing larger particles and be lost (Adams and Seinfeld, 2002). Globally, according to large-scale model simulations, atmospheric new particle formation (NPF) and subsequent particle growth represent the most significant source of atmospheric aerosol particles, at least in terms of their total number concentration (Kulmala et al., 2004; Makkonen et al., 2009; Merikanto et al., 2009; Pierce and Adams, 2009; Wang and Penner, 2009; Yu and Luo, 2009). An increase of the number concentration of particles that can act as $\mathrm{CCN}$ results in higher CDNC and brighter clouds with longer lifetimes.

Globally, organic particulate matter makes up more than $50 \%$ of the sub-micrometer mass concentration of ambient aerosols in locations throughout the world (Kanakidou et al., 2005; Seinfeld and Pandis, 2006; Zhang et al., 2007). Nearly 70\% of this material is thought to be secondary organic aerosol (SOA) formed from the oxidation of volatile organic compounds (VOCs) (Hallquist et al., 2009; Schulze et al., 2017). Many of the relevant precursor VOCs are biogenic in origin, such as monoterpenes $\left(\mathrm{C}_{10} \mathrm{H}_{16}\right)$ and isoprene $\left(\mathrm{C}_{5} \mathrm{H}_{8}\right)$.

Several recent field studies have shown that SOA in polluted areas cannot be explained by the simulation of only the first generation of reactions of "traditional" SOA precursors: biogenic compounds (monoterpenes, sesquiterpenes, and isoprene) and anthropogenic compounds (aromatics, olefins and large alkanes) (de Gouw et al., 2005; Volkamer et al., 2006; Kleinman et 
become clear that organic vapors are responsible for most of the new particle growth in environments with low sulfur dioxide levels (Olenius et al., 2018; Yli-Juuti et al., 2020).

Traditional treatment of SOA formation considers only VOCs as the precursors and only semivolatile products (Odum et al., 1996). Robinson et al. (2007) suggested that intermediate volatile organic compounds (IVOCs) either emitted directly or resulting from the evaporation of particles may be an important and previously neglected pool of precursors for SOA formation. In addition, later generations of reactions of the products of VOCs, IVOCs and SVOCs can lead to products of even lower volatility and formation of SOA (Donahue et al., 2006). These chemical reactions can lead to continued SOA production after complete precursor consumption as products undergo further oxidation (Kroll et al, 2006; $\mathrm{Ng}$ et al., 2006).

Secondary extremely low volatile organic compounds (ELVOCs) have been detected both in the ambient atmosphere and laboratory studies (Donahue et al., 2011). These compounds promote new particle growth and CCN production in the atmosphere (Jokinen et al., 2015; Kirkby et al., 2016). ELVOCs can be produced rapidly in the gas phase during monoterpene oxidation (Ehn et al., 2014), and can enhance atmospheric new particle formation and growth (Jokinen et al., 2015). Due to their exceptionally low volatility, ELVOCs condense essentially irreversibly onto growing particles at a rate controlled by the Fuchs-adjusted particle surface area (Shrivastava et al., 2017).

Fanourgakis et al. (2019) evaluated 16 global chemistry transport models during a 4-year period and compared their prediction to the near-surface observed number concentration of aerosol particles across Europe and Japan. All models tended to underestimate the number concentrations for particles larger than $50 \mathrm{~nm}\left(N_{50}\right)$. The normalized mean bias (NMB) was $-51 \%$ and normalized mean error (NME) was 55\% for all stations. Sengupta et al. (2021) used the GLOMAP (Global Model of Aerosol Processes; Spracklen et al., 2005) modal aerosol microphysics model (Mann et al., 2010) simulating the production of six surrogate SOA species from the oxidation of anthropogenic VOCs, monoterpenes, and isoprene. They assumed that ELVOCs derive only from biogenic sources and can nucleate to form new particles (Gordon et al., 2016). Concentrations of particles larger than $3 \mathrm{~nm}\left(N_{3}\right)$ and particles larger than $50 \mathrm{~nm}\left(N_{50}\right)$ were consistently underestimated, while the best model performance was achieved when the ELVOC yield from precursor VOCs was around $13 \%$. These studies suggest that the role of organics and especially ELVOCs on particle formation and growth is still not well understood. 
In this study we extend the three-dimensional regional chemical transport model (CTM), PMCAMx-UF (Jung et al., 2010), with detailed aerosol microphysics (Gaydos et al., 2007; Karydis et al., 2007) that has been used and evaluated for simulations over the US and Europe (Fountoukis et al., 2012). Originally the model assumed that growth of new particles was exclusively due to sulfuric acid and ammonia condensation while the semivolatile secondary organics condensed only on the accumulation mode thus contributing to the condensation and coagulation sinks. This initial model version was found to reproduce more than $70 \%$ of the hourly number concentrations of particles larger than $10 \mathrm{~nm}\left(N_{10}\right)$ within a factor of 2 (Fountoukis et al., 2012). However, the concentration of particles larger than $100 \mathrm{~nm}\left(N_{100}\right.$, a proxy for the number of particles that can act as $\mathrm{CCN}$ ) was systematically underpredicted. The growth rates were also underpredicted, with smaller errors in sites where the sulfate to organics mass ratio was high. These problems were caused mainly by insufficient organic vapor condensation (Fountoukis et al., 2012) on ultrafine particles. Patoulias et al. (2018) developed an extended version of PMCAMx-UF in which the SOA components were modeled as semi-volatile first-generation products of the oxidation of VOCs. The model predictions were compared against size distribution measurements from 16 stations in Europe during a photochemically active period. Including SOA condensation on ultrafines in PMCAMx-UF improved its ability to reproduce the $N_{10}$ and $N_{100}$ concentration at ground level. The inclusion of SOA decreased the daily normalized mean bias (NMB) of $N_{10}$ from $85 \%$ to $75 \%$ and the daily NMB of $N_{100}$ from $40 \%$ to $20 \%$. However, the results suggested that there is a need for additional improvements.

The primary goal of this study is to examine the role of IVOCs and ELVOCs on particle number concentrations in Europe. PMCAMx-UF is extended once more to simulate the multiple generations of IVOC gas-phase oxidation and the production of ELVOCs by monoterpenes. The model predictions are compared with measurements from 26 sites during the intensive field campaign that took place in Europe, as part of the Pan-European-Gas-AeroSOl-climate-interaction Study (PEGASOS) project, from June 5 to July 8, 2012. The airborne data obtained by a Zeppelin measuring above Po-Valley during the same campaign are also used. An analysis of the Zeppelin measurement can be found by Lampilahti et al. (2021). 


\section{Model description}

PMCAMx-UF is a three-dimensional chemical transport model (CTM) that simulates the aerosol number size distribution in addition to the mass/composition size distribution (Jung et al., 2010; Fountoukis et al., 2012) and is described in detail in Patoulias et al. (2018). PMCAMx-UF is based on the framework of PMCAMx (Gaydos et al., 2007; Karydis et al., 2007), describing the processes of horizontal and vertical advection, emissions, horizontal and vertical dispersion, wet and dry deposition, aqueous and aerosol phase chemistry, as well as aerosol dynamics and thermodynamics.

For the simulation of aerosol microphysics, PMCAMx-UF uses the updated version of DMANx which simulates the processes of coagulation, condensation/evaporation and nucleation (Patoulias et al., 2015) with the two-moment aerosol sectional (TOMAS) algorithm (Adams and Seinfeld, 2002; Jung et al., 2006). A key feature of TOMAS is its ability to track two independent moments of the aerosol size distribution for each size bin: the aerosol number and mass concentration.

The aerosol size distribution is discretized into 41 sections covering the diameter range from approximately $0.8 \mathrm{~nm}$ to $10 \mu \mathrm{m}$. The lowest boundary is at $3.75 \times 10^{-25} \mathrm{~kg}$ of dry aerosol mass per particle. Each successive boundary has twice the mass of the previous one. The particle components modeled include sulfate, ammonium, nitrate, sodium, chloride, crustal material, water, elemental carbon, primary organic aerosol (POA) and eight surrogate SOA components.

In this work, the nucleation rate is calculated using a scaled ternary parameterization based on the original expressions of Napari et al. (2002) with a scaling factor of $10^{-6}$ following the suggestions of Fountoukis et al. (2012). The binary parameterization of Vehkamäki et al. (2002) is employed if the $\mathrm{NH}_{3}$ concentration is below a threshold value of $0.01 \mathrm{ppt}$.

Coagulation of particles in the atmosphere is an important sink of aerosol number but is also a mechanism by which freshly nucleated particles grow to larger sizes. Following Adams and Seinfeld (2002), TOMAS assumes that the aerosol particles coagulate via Brownian diffusion and the effects of gravitational settling and turbulence are negligible. The calculation of the coagulation coefficients is based on the wet diameters of the particles. These wet diameters are calculated following the approach of Gaydos et al. (2005). For small particles $(<100 \mathrm{~nm})$, we use the expression of Dahneke et al. (1983) to correct for non-continuum effects. The coagulation algorithm uses an adaptive time step. The time step is limited so that the aerosol number or mass 
concentration in any size category does not increase by more than an order of magnitude or decrease by more than $25 \%$ in each step.

The extended SAPRC (Statewide Air Pollution Research Center) chemical mechanism (Carter, 2000; Environ, 2003), which includes 219 reactions of 64 gases and 18 free radicals, is used for the gas phase chemistry mechanism in PMCAMx-UF. The SAPRC version used for this work includes five lumped alkanes (ALK1-5), two lumped olefins (OLE1-2), two lumped aromatics (ARO1-2), isoprene (ISOP), a lumped monoterpene (TERP) and a lumped sesquiterpene species (SESQ).

\subsection{Secondary organic aerosol formation}

Gas-phase oxidation of volatile organic compounds (VOCs) produces semi-volatile and low-volatility products that can then condense to the particle phase. The volatility-basis set (VBS) framework used in PMCAMx-UF (Donahue et al., 2006) describes the volatility distribution of the OA compounds. SOA is formed from anthropogenic (aSOA) and biogenic (bSOA) precursors. Each of these types is simulated with 5 volatility bins with saturation concentrations of $10^{-5}, 1,10$, 100 and $1000 \mu \mathrm{g} \mathrm{m}^{-3}$. The $10^{-5} \mu \mathrm{g} \mathrm{m}^{-3}$ bin was added in this work to describe the ELVOCs. We assumed an average molecular weight of $200 \mathrm{~g} \mathrm{~mol}^{-1}$ for SOA, and an effective enthalpy of vaporization of $30 \mathrm{~kJ} \mathrm{~mol}^{-1}$ (Pathak et al., 2007; Stanier et al., 2007). The SOA yields used in this version of PMCAMx-UF for the semi-volatile components are the $\mathrm{NO}_{\mathrm{x}}$-dependent stoichiometric yields of Murphy at al. (2009).

Chemical reactions that change the volatility of the organics in the gas phase will change the OA mass by influencing their partitioning. In PMCAMx-UF all secondary species are treated as chemically reactive. Further gas-phase oxidation of OA vapors (chemical aging) is modeled using a second-order reaction with hydroxyl radicals and a rate constant of $1 \times 10^{-11} \mathrm{~cm}^{3} \mathrm{molec}^{-1} \mathrm{~s}^{-1}$ (Atkinson and Arey, 2003). Each reaction is assumed to reduce the volatility of the vapor material by one order of magnitude (i.e., shifting material from a $\mathrm{C}^{*}$ of 100 to $10 \mu \mathrm{g} \mathrm{m}^{-3}$ ), with a small increase in mass (7.5\%) to account for the added oxygen (Lane et al., 2008; Shrivastava et al., 2008). Intermediate volatility organic compounds (IVOCs), are distributed in the $10^{3}, 10^{4}, 10^{5}$, and $10^{6} \mu \mathrm{g} \mathrm{m}^{-3}$ saturation concentration bins. The emission rates of the IVOCs are assumed to be equal to $0.3,0.4,0.5$ and 0.8 times the original non-volatile POA emission rate, for the $10^{3}-10^{6}$ bins respectively (Robinson et. 2007). 
ELVOCs were assumed to be produced by the oxidation of monoterpenes with a molar yield of 5\%. For comparison, ELVOC yields for the $\alpha$-pinene ozonolysis in Jokinen et al. (2015) were $3.4 \pm 1.7 \%$, by Ehn et al. (2014) of $7 \pm 4 \%$ and $4.5 \pm 3.8 \%$ in Rissanen et al. (2014). An average molecular weight of $200 \mathrm{~g} \mathrm{~mol}^{-1}$ for ELVOCs was assumed in this work.

The partitioning of OA between the gas and particulate phases is simulated dynamically in PMCAMx-UF without assuming equilibrium (Patoulias et al., 2015). The driving force for condensation of a vapor to an aerosol particle is the difference between its ambient vapor partial pressure and the equilibrium vapor pressure over the particles, with the latter including the Kelvin effect which is due to the curvature of the particles. The Kelvin effect is larger for the smaller particles and acts as a barrier for the condensation of organic vapors on these particles. In this simulation a surface tension of $\sigma=0.025 \mathrm{Nm}^{-1}$ is assumed for all SOA components (Pierce et al., 2011; Patoulias et al. 2015).

Three different chemical aging schemes are used in this work (Table S1). The first scheme (case 1 or base case) includes (i) the aging of SOA components from anthropogenic sources, using a rate constant $k(298 \mathrm{~K})=10 \times 10^{-12} \mathrm{~cm}^{3} \mathrm{molec}^{-1} \mathrm{~s}^{-1}$ (anthropogenic SOA aging), (ii) the aging of IVOCs using a rate constant $k(298 \mathrm{~K})=40 \times 10^{-12} \mathrm{~cm}^{3} \mathrm{molec}^{-1} \mathrm{~s}^{-1}$, (iii) production of ELVOCs with saturation concentration of $10^{-5} \mu \mathrm{g} \mathrm{m}^{-3}$ from the oxidation of monoterpenes with a yield of $5 \%$. The aSOA aging rate constant is based on $\mathrm{OH}$ oxidation of the products of aromatic VOCs oxidation (Atkinson 2000; 2003). No biogenic SOA aging was simulated in this case, an assumption based on laboratory studies (Presto et al., 2006; Ng et al., 2006) and the results of Lane et al. (2008). In the second simulation (case 2), the ELVOC yield was set to zero thus neglecting their formation. The rest of the parameters were the same as in the base case. Finally, in the third simulation the emissions of IVOCs and the chemical aging reactions of all VOCs were neglected while the production of the ELVOCs was simulated similarly to the base case.

\subsection{Model application and measurements}

The PMCAMx-UF modeling domain in this application covers a $5400 \times 5832 \mathrm{~km}^{2}$ region in Europe, with a $36 \times 36 \mathrm{~km}$ grid resolution and 14 vertical layers extending up to approximately $7.2 \mathrm{~km}$. The modeling period covers 34 days, from June 5 to July 8, 2012 corresponding to the PEGASOS 2012 intensive period. PMCAMx-UF was set to perform simulations on a rotated polar stereographic map projection. The first two days of each simulation were excluded from the 
217 analysis to minimize the effect of the initial conditions on the results. For the boundary conditions, constant and relatively low values have been used (Table S2) so that the predicted particle number concentrations over central Europe are determined for all practical purposes by the emissions and corresponding processes simulated by the model. The effect of these boundary conditions on the predicted number concentrations are discussed in Patoulias et al. (2018).

Meteorological inputs to PMCAMx-UF include horizontal wind components, vertical diffusivity, temperature, pressure, water vapor, clouds and rainfall. The Weather Research and Forecasting (WRF) model (Skamarock et al., 2005) was used to generate the above inputs. WRF was driven by geographical and dynamic meteorological data generated by the Global Forecast System. Each layer of PMCAMx-UF was aligned with the layers used in WRF. The WRF simulation was periodically re-initialized every 3 days with observed conditions to ensure accuracy in the corresponding fields used as inputs in PMCAMx-UF. The measurements were pre-processed by the WPS (WRF Preprocessing System) package, which provides each atmospheric and static field with fidelity appropriate to the chosen grid resolution of the model. The performance of WRF for Europe against observed meteorological variables has been the topic of several recent studies (Jimenez-Guerrero et al., 2008; de Meij et al., 2009; Im et al., 2010; Argueso et al., 2011; GarciaDiez et al., 2012) demonstrating good performance.

The particle emissions were based on the pan-European anthropogenic particle number emission inventory (Denier van der Gon et al., 2009; Kulmala et al., 2011) and the carbonaceous aerosol inventory (Kulmala et al., 2011) developed during the EUCAARI (European Integrated project on Aerosol, Cloud, Climate, and Air Quality Interactions) project. The resulting number/mass inventories includes both number emissions and consistent size-resolved composition for particles over the size range of approximately $10 \mathrm{~nm}$ to $10 \mu \mathrm{m}$. Hourly gridded anthropogenic and biogenic emissions included both gases and primary particulate matter. The natural emissions include both particulate matter and gases and combine three different data sets: emissions from ecosystems based on the Model of Emissions of Gases and Aerosols from Nature (MEGAN; Guenther et al., 2006), marine emissions based on the model of O'Dowd et al. (2008) as sea surface covers a considerable area of the domain, and wildfire emissions (Sofiev et al., 2008a, b). MEGAN uses as inputs the plant functional type, the leaf area index, various chemical species emission factors and weather data provided by the WRF. Wind speed fields from WRF and chlorophyll-a concentrations were used as inputs of the marine aerosol model. VOCs were 
speciated based on the approach proposed by Visschedijk et al. (2007). Anthropogenic gas emissions included land emissions from the GEMS (global and regional Earth-system monitoring using satellite and in-situ data) dataset (Visschedijk et al., 2007). The international shipping, industrial, domestic, agricultural and traffic aerosol emission sources were included in the anthropogenic inventory (Denier van der Gon et al., 2009; Kulmala et al., 2011).

The model results were compared against measurements in 26 ground sites, which are available in the European Supersites for Atmospheric Aerosol Research (EUSAAR), and EBAS databases (https://ebas.nilu.no) and the Aerosols, Clouds and Trace gases Research Infrastructure (ACTRIS) (https://actris.nilu.no). Particle size distribution measurements at all sites were made using either a Differential Mobility Particle Sizer (DMPS) or a Scanning Mobility Particle Sizer (SMPS). Information about all stations can be found in Table S3.

An intensive field campaign took place in Europe, as part of the Pan-European-GasAeroSOl-climate-interaction Study (PEGASOS) project, from June 5 to July 8, 2012. Measurements of aerosol mass concentration $\mathrm{PM}_{1}$ (particulate matter particles of diameter less than 1 micrometer) from the PEGASOS project are also available for the same period for Patras (Greece), Finokalia (Greece), San Pietro Capofiume (Italy) and Bologna (Italy) (Table S4) and filter $\mathrm{PM}_{2.5}$ (particulate matter particles of diameter less than 2.5 micrometer) measurements from 6 additional stations in Europe (Table S5). For the calculation of organic mass, we used an average organic mass to organic carbon ratio value equal to 1.8 (Kostenidou et al., 2015).

The airborne measurements acquired by the PEGASOS Zeppelin were acquired during the simulation period over the Po Valley. The Po Valley region is situated between the Alps in the north and the Apennines Mountains in the south-southwest. The mountains surround the valley on three sides and high levels of pollutants are often observed in the region due to the industrial, agricultural, and other anthropogenic emissions. In addition, emissions from ship traffic on the Adriatic Sea (Hamed et al., 2007) and long-range transport from central-eastern Europe also contribute pollutants to the region (Sogacheva et al., 2007). A SMPS was used to measure the number size distribution of particles in the size range of 10 to $430 \mathrm{~nm}$. Details of the relevant PEGASOS Zeppelin measurements can be found in Lampilahti et al. (2021). 
279

280

281

\section{Results}

\subsection{Base case}

The average predicted ground level average number concentrations for the total number of particles $\left(N_{\text {tot }}\right)$ and for particles with diameters above $10 \mathrm{~nm}\left(N_{10}\right), 50 \mathrm{~nm}\left(N_{50}\right)$ and $100 \mathrm{~nm}\left(N_{100}\right)$, during June 5 to July 8, 2012 are shown in Figure 1. The $N_{50}$ and $N_{100}$ concentrations are often used as proxies for CCN number concentrations (Fountoukis et al., 2012). On a domain average basis, the model predicted for the ground level $4780 \mathrm{~cm}^{-3}$ for $N_{\text {tot }}, 3630 \mathrm{~cm}^{-3}$ for $N_{10}, 1990 \mathrm{~cm}^{-3}$ for $N_{50}$, and $820 \mathrm{~cm}^{-3}$ for $N_{100}$ during the simulated period. The highest $N_{\text {tot }}$ average concentrations (more than $15000 \mathrm{~cm}^{-3}$ ) were predicted over Bulgaria, southern Romania, Turkey, Poland, Holland, Portugal, Northern Spain, Eastern UK and Russia. On the other hand, the highest $N_{50}$ and $N_{100}$ are predicted over the Mediterranean, mainly in areas near Southern Spain, Southern Italy, and the Balkans. The $N_{\text {tot }}$ and $N_{10}$ are high in areas of frequent nucleation events and areas with high particle number emissions, whereas the $N_{50}$ and $N_{100}$ levels are affected significantly by secondary particulate matter production. The high photochemical activity over the Eastern Mediterranean leads to the corresponding high levels of $N_{50}$ and $N_{100}$ during this period.

\subsection{Evaluation of PMCAMx-UF predictions}

\subsubsection{Comparison of PMCAMx-UF predictions to ground aerosol number observations}

The prediction skill metrics of PMCAMx-UF, for the daily average ground measurements from the 26 stations, are summarized in Tables 1 and 2 for both the base case and the case in which the ELVOCs are neglected.

For the base case simulation, the model has a tendency to overestimate the $N_{10}$ levels. The normalized mean bias (NMB) for the daily average concentrations is $23 \%$ and the normalized mean error (NME) 63\%. The $N_{10}$ was overpredicted in 18 sites, underpredicted in 7 and there was no bias in one. The NMB in 8 sites (Prague-Suchdol, Ispra, Melpitz, Patras, K-Puszta, Hohenpeissenberg, Hyytiala and San Pietro Capofiume) was less than $\pm 15 \%$, and for another 8 stations between $\pm 15 \%$ and $\pm 40 \%$ (Annaberg-Buchholz, Cabauw, Dresden Nord and Winckelmannstrasse, Finokalia, Giordan Lighthouse, Kosetice, Montseny and Varrio). The highest discrepancies with the measurements of $N_{10}$ were found in Aspvreten, Birkness II, Usti n.L.-mesto, Vavihill, Vielsalm, Zugspitze-Schneefernerhaus, Waldhof, Costa Navarino, and Thesssaloniki with NMB higher than $\pm 40 \%$. 
The model performed better for $N_{100}$. There was little bias in the corresponding predictions on average (the NMB was -10\%) and the NME was 45\%. The NMB for 10 sites (Cabauw, Giordan Lighthouse, Hyytiala, Kosetice, Melpitz, Patras, Prague-Suchdol, Vielsalm, Waldhof and Zugspitze) was less than $\pm 15 \%$ and for another 12 (Annaberg-Buchholz, Birkenes II, Dresden Nord and Winckelmannstrasse, Finokalia, Hohenpeissenberg, Ispra, K-Puszta, Montseny, Costa Navarino, San Pietro Capofiume, Usti n.L-mesto. and Vavihill) between $\pm 15 \%$ and $\pm 40 \%$ (Table 2). The absolute NMB for $N_{100}$ exceeded $40 \%$ only in Aspvreten, Varrio and Thessaloniki.

\subsubsection{Evaluation of aerosol composition predictions}

The PMCAMx-UF predictions can be evaluated during that period using available $\mathrm{PM}_{1}$ measurements from Aerosol Mass Spectrometers at four stations (Bologna and San Pietro Capofiume, in Italy and Finokalia and Patras, in Greece) that were part of the PEGASOS campaign.

In Italy and Greece, the model reproduces the observations of the $\mathrm{PM}_{1}$ concentrations of the major inorganic aerosol components (sulfate, ammonium, nitrate) reasonably well (Table 3). The model tends to underpredict the organic aerosol concentrations in Patras and Bologna, while it overpredicts the OA in Finokalia and San Pietro Capofiume (Table 4). The OA NMB is -2\% and the NME is $38 \%$, with the Finokalia site presenting the higher NMB value $(50 \%)$ and San Pietro Capofiume, Bologna the lower $( \pm 20 \%)$ (Table 4$)$.

For the rest of Europe, $\mathrm{PM}_{2.5}$ filter measurements have been used, available in the European Supersites for Atmospheric Aerosol Research (EUSAAR) and EBAS databases (http://ebas.nilu.no/) for stations that had available data for more than 15 days during the simulated period (6 additional stations in Europe: Payerne, Melpitz, Montseny, Ispra, Diabla Gora, and Iskrba; Table 5). For the calculation of $\mathrm{OA}$ mass concentration, we assumed $\mathrm{OA}: \mathrm{OC}=1.8$ (Kostenidou et al., 2015). For these sites, the model has a tendency towards overestimating the $\mathrm{PM}_{2.5}$ OA concentration for 4 out of 6 stations, presenting an average NMB of $20 \%$ and NME of $62 \%$ (Table 5).

\subsubsection{Comparison of PMCAMx-UF predictions to Zeppelin measurements}

One of the challenges of the PMCAMx-UF evaluation using airborne measurements is that the model predictions are available every 15 min while the corresponding measurements by the Zeppelin were taken every 3 min in different heights. For comparison purposes, the model output 
was interpolated to the times of the Zeppelin measurement periods. PMCAMx-UF reproduced more than $75 \%$ of the $20003-\min N_{10}$ and $N_{100}$ measurements by the Zeppelin with a factor of 2 (Figure S1). The vertical profiles shown in Fig.2, are averages of different flights that collected data in different days and different altitudes each time. The number of samples at different altitudes changed for each flight creating additional variability in the measured profiles.

To facilitate the comparison between measurements and predictions the corresponding average profiles (matched in space and time) were calculated using $80 \mathrm{~m}$ altitude bins for all the PEGASOS flights. PMCAMx-UF reproduced on average the $N_{10}$ measurements over Po Valley at the lower $160 \mathrm{~m}$ and above $400 \mathrm{~m}$, but underestimated the higher $N_{10}$ levels measured in the residual layer at heights between $160-400 \mathrm{~m}$ at several of the flights that started several hours before sunrise (Fig. 2a). The average measured $N_{l 0}$ at all heights was $6,000 \mathrm{~cm}^{-3}$, while the predicted concentration was equal to $4,700 \mathrm{~cm}^{-3}$.

PMCAMx-UF reproduced well the $N_{100}$ concentration at all heights (Fig 2b). The model also reproduced $80 \%$ of the 3 -min $N_{100}$ Zeppelin measurements within a factor of 2 . The measured average $N_{100}$ at all heights was $1,500 \mathrm{~cm}^{-3}$ and the average predicted by PMCAMx-UF was 1,800 $\mathrm{cm}^{-3}$. The ability of the revised model to reproduce reasonably well the high-time resolution (3minute) Zeppelin measurements at multiple altitudes and locations is encouraging.

\subsection{Effect of ELVOC production on particle number and OA concentrations}

An additional simulation was performed neglecting the production of ELVOCs from terpenes (case 2). The addition of ELVOCs, increased the $\mathrm{PM}_{2.5} \mathrm{OA}$ mass by approximately as much as $0.5 \mu \mathrm{g} \mathrm{m}^{-3}$ in Central/Eastern Europe and Russia, accounting for approximately $10-15 \%$ of the OA (Fig. 3). In these areas a combination of high terpene emissions and high photochemical reaction rates existed during the simulated period. The highest relative predicted increase of OA was $15-25 \%$ in northern Europe. In central Europe the ELVOC formation increased average OA by approximately $10 \%$.

The average fractional increase of $N_{x}$, due to the production of ELVOCs is calculated as:

$$
f_{N x}=\frac{N_{x} \text { (with ELVOCs) }-N_{x} \text { (without ELVOCs) }}{N_{x} \text { (without ELVOCs) }}
$$

where, $x$, is $10,50,100 \mathrm{~nm}$ or zero (total number). Rather surprisingly, the average fractional change for all number concentrations $\left(N_{\text {tot }}, N_{10}, N_{50}\right.$ and $N_{100}$, ) is small ranging between $1 \%$ and $4 \%$ (Fig. 4 ) $\left(N_{\text {tot }}:-8 \mathrm{~cm}^{-3}\right.$ or $-0.14 \%, N_{10}: 40 \mathrm{~cm}^{-3}$ or $-1.14 \%, N_{50}: 60 \mathrm{~cm}^{-3}$ or $3 \%, N_{100}: 35 \mathrm{~cm}^{-3}$ or 
$4 \%)$. One reason for the small average change is that both increases and decreases are predicted for different areas in Europe. These mixed results are due to the fact that the ELVOC condensation accelerates the growth of new and preexisting particles to larger sizes, but at the same time accelerates their losses due to the increase of the coagulation sink and decreases the nucleation rate due to the increase of the condensation sink.

The formation of ELVOCs resulted in a predicted decrease of $N_{\text {tot }}$ by $20 \%\left(300-600 \mathrm{~cm}^{-3}\right)$ in parts of the Nordic countries and by 5\% in central Europe (Fig. 4). The decreases are predicted for most Europe with the exception of a few areas in which increases are predicted (northern Iberian Peninsula, parts of France, areas in the Balkans with high sulfur dioxide levels, etc.) (Fig. 5). The predicted $N_{10}$ increased by $5-15 \%\left(150-400 \mathrm{~cm}^{-3}\right)$ over Finland, northwestern Russia, France, Ireland and northern Portugal. At the same time there were small decreases of a few percent over several areas in Europe especially in the south and in the east as well over the Baltic Sea. $N_{50}$ increased over almost of Europe by 50 to $300 \mathrm{~cm}^{-3}$. This $N_{50}$ increase corresponds to $20-40 \%$ over Scandinavia and northwestern Russia, and 10\% for central Europe. Finally, the ELVOCs caused an increase in $N_{100}$ of $20-50 \%$ over Scandinavia and 10-20\% increases over central Europe. The absolute corresponding $N_{100}$ changes in these areas are $100-200 \mathrm{~cm}^{-3}$.

The corresponding changes of the number concentrations for particles with diameters between 1 and $10 \mathrm{~nm}\left(\mathrm{~N}_{1-10}\right), 10$ and $50 \mathrm{~nm}\left(\mathrm{~N}_{10-50}\right)$ and (iii) 50 and $100 \mathrm{~nm}\left(N_{50-100}\right)$ are summarized in Fig. S2. These figures illustrate the complex effect of the ELVOCs on different parts of the aerosol number distribution. Decreases in the concentrations of the 1-10 nm particles (decreasing nucleation rate due to increased condensation sink, increasing coagulation with larger particles), increases in the concentrations of the particles larger than $100 \mathrm{~nm}$ (due to accelerated growth of the sub-100 $\mathrm{nm}$ particles to larger sizes) and both increases and decreases in the 10-50 $\mathrm{nm}$ size range depending on the magnitude of the different competing processes in each area. The effect of the ELVOCs in this PMCAMx simulation is clearly a lot more complex than a uniform increase of particle number concentrations.

The results in the Hyytiala station in Finland were examined in more detail because the predicted number concentrations in Finland are quite sensitive, according to PMCAMx-UF, to the addition of the ELVOCs. The predicted $N_{3}, N_{10}, N_{50}$ and $N_{100}$ concentrations for the base case are in reasonable agreement with the field measurements in this area (Figure S3), with a tendency of the model to overpredict the $N_{3}$ levels during a few nucleation events. For all concentrations the 
simulation with the ELVOCs (base case) reproduces the measurements better than the simulation in which they are neglected. The condensation sink (CS) for Hyytiala increases by a few percent due to the additional mass of the ELVOCs (Figure S3). The average measured and predicted number size distributions in Hyytiala site (Finland) are shown in Figure S4. The addition of the ELVOCs leads to increased levels in the part of the size distribution above $50 \mathrm{~nm}$. A decrease of the concentration of particles with diameter below $7 \mathrm{~nm}$ is predicted due to the addition of the ELVOCs because of both increased coagulation losses but also lower nucleation rates.

The ELVOC addition played a minor role on the overall performance of PMCAMx-UF. The NMB for $N_{10}$ decreased (in absolute terms) by $1 \%$, it increased by $5 \%$ for $N_{100}$ due to the addition of the ELVOCs in the simulation (Table 1-2). The addition of the ELVOCs affects mainly the PMCAMx-UF predictions in northern Europe and especially Finland, where the predictions of $N_{100}$ significantly improve. In Hyytiala site the NMB decreases from $-34 \%$ to $-14 \%$ and in Varrio drops from $-72 \%$ to $-49 \%$. The corresponding normalized mean errors changed by $1-2 \%$. These small changes in the performance metrics are consistent with the small overall changes caused by the ELVOC addition.

The small change in the OA mass concentration due to the addition of the ELVOCs has a modest impact on the performance of PMCAMx-UF for OA (Table S6 and S7). For example, the $\mathrm{PM}_{1}$ OA bias improves from $-6 \%$ to $2 \%$ while the $\mathrm{PM}_{2.5}$ OA bias increases from $15 \%$ to $20 \%$. The changes in normalized error are $1 \%$ or less.

\subsection{Effect of IVOCs on particle number concentrations}

The emissions of IVOCs $\left(\mathrm{C}^{*} \geq 10^{-3} \mu \mathrm{g} \mathrm{m}^{-3}\right)$ were set to zero in a sensitivity test (Case 3$)$ to quantify their effect on the predicted particle number concentration and size distribution. The SOA formed by the IVOCs (SOA-iv) exceeds $1 \mu \mathrm{g} \mathrm{m}{ }^{3}$ in southern Europe, over the Mediterranean Sea, but also in large areas over central and eastern Europe (Fig. 6). The high SOA-iv levels over the Mediterranean are due to the oxidation of IVOCs emitted from large wildfires that occurred during the simulation period. The corresponding SOA-iv is $10-25 \%$ of the total OA over continental Europe and even higher (about 60\%) over parts of the marine atmosphere.

According to PMCAMx-UF the addition of the emissions of IVOCs and their aging reactions lead to a reduction of $N_{\text {tot }}$ by $5-10 \%$ and $N_{10}$ by $5 \%$ (Fig. 7) for continental Europe. On the other hand, this addition of IVOCs leads to an increase of $N_{50}$ by $5 \%$ and $N_{100}$ by $5-10 \%$ mainly 
in central Europe and the Mediterranean Sea (Fig. 7). The corresponding changes of the number concentrations for the various size ranges $N_{1-10}, N_{10-50}$ and $N_{50-100}$ are summarized in Fig. 8. The predicted $N_{1-10}$ decreases approximately $15-20 \%$ for most of Europe except for the Scandinavian peninsula due to the IVOCs. $N_{10-50}$ decreases $10-15 \%$ mainly in southern Europe and $N_{50-100}$ changes less than $\pm 5 \%$ or $\pm 100 \mathrm{~cm}^{-3}$ in the simulated domain.

The atmospheric oxidation of the emitted IVOCs produces semi-volatile organic compounds, which condense preferentially on particles in the accumulation mode and not so much on the smallest particles due to the Kelvin effect. This results in an increase of both the condensation and coagulation sinks, which then lead to a decrease of the nucleation rate but also on the coagulation rate of the smaller with the larger particles.

The effect of the addition of the IVOCs on the performance of PMCAMx-UF is modest and mixed. The NMB for $N_{10}$ increased by $4 \%$ (from $23 \%$ to $27 \%$ ) and decreased by $5 \%$ for $N_{100}$ (from $10 \%$ to $5 \%$ ) (Table S5). The corresponding NME for both $N_{10}$ and $N_{100}$ changed slightly (approximately 1\%). The modest overall changes on the number distribution of the ultrafine particles caused by the addition of IVOCs and the corresponding aging reactions are consistent with the small changes in the PMCAMx-UF performance metrics.

The addition of the IVOCs and the resulting SOA-iv from their oxidation also had mixed results in the PMCAMx-UF performance for OA in Europe. This added SOA removed the underprediction of OA against the AMS measurements in Italy and Greece; the NMB changed from $-18 \%$ when IVOCs were neglected to $2 \%$ when IVOCs were included (Table S8). The NME increased a little (from $35 \%$ to $35 \%$ ) with the IVOC addition. The performance against the OA measurements in the other European sites became a little worse when IVOCs were included in the model (Table S9). The small underprediction $(\mathrm{NMB}=-8 \%)$ in $\mathrm{OA}$ became a larger overprediction $(\mathrm{NMB}=20 \%)$ and the NME increased from $50 \%$ to $62 \%$. These results are characteristic of the uncertainties in primary OA emissions but also SOA production from the various VOCs and IVOCs emitted by anthropogenic and biogenic sources.

\section{Conclusions}

A new version of PMCAMx-UF was developed with the ability to simulate the formation and dynamic condensation of ELVOCs during the oxidation of the monoterpenes and the emissions and multi-generational chemistry of IVOCs. The model was applied to the PEGASOS 
summer intensive period campaign during the summer of 2012. The available measurements included both ground stations across Europe and airborne measurements from a Zeppelin over the Po Valley.

The number concentration predictions of PMCAMx-UF, are compared against ground measurements from 26 stations in Europe. The model tends to overestimate daily average $N_{10}$ with a normalized bias of $35 \%$ and an average error of $64 \%$. PMCAMx-UF performed well for $N_{100}$ with a low bias (-2\%) and an error of $41 \%$. The performance of the model in the lowest $1 \mathrm{~km}$ of the atmosphere above Po Valley for both $N_{10}$ and $N_{100}$ was even better than its average performance over Europe. The model's predicted $\mathrm{PM}_{1}$ and $\mathrm{PM}_{2.5}$ concentrations and composition had $\mathrm{NMB}$ of $15 \%$ and errors less than $60 \%$ depending on the PM component. These results suggest that PMCAMx-UF does a reasonable job reproducing the aerosol mass and number concentrations over Europe during the simulated period.

The ELVOCs produced by the monoterpene oxidation contributed, according to the PMCAMx-UF predictions on average around $0.5 \mu \mathrm{g} \mathrm{m}^{-3}$ and accounted for $10-15 \%$ of the $\mathrm{PM}_{2.5}$ OA. The highest relative predicted increase of OA was 15-25\% in northern Europe, while the ELVOC formation increased average OA by approximately $10 \%$ in central Europe.

The ELVOC production by monoterpenes led to surprisingly small changes of the average number concentrations over Europe. The total number concentration decreased by $0.2 \%$, the $N_{10}$ decreases by $1.1 \%$, while $N_{50}$ increased by $3 \%$ and $N_{100}$ by $4 \%$ due to this new SOA source. One of the reasons for these small average increases is the nonlinearity of the system leading to both increases and decreases in different parts of Europe. Even if ELVOCs accelerate the growth of the newly formed particles to larger sizes increasing in this way their lifetime, at the same time they increase the aerosol mass and surface area as they mostly condense on the accumulation mode. Therefore, they increase the condensation sink, decreasing the sulfuric acid supersaturation and the corresponding nucleation rate. They also increase the coagulation sink and thus accelerate the removal of all nanoparticles.

Locally the effects of the ELVOC production could be higher. For example, it is estimated that the ELVOC productions leads to a decrease of the total particle concentration $N_{\text {tot }}$ by $20 \%$ in parts of the Nordic countries and by $5 \%$ in central Europe. At the same time, the predicted $N_{10}$ increased by $5-15 \%\left(150-400 \mathrm{~cm}^{-3}\right)$ over Finland, northwestern Russia, France, Ireland and northern Portugal due to these secondary organic compounds. The predicted $N_{50}$ increased almost 
everywhere in continental Europe by $50-300 \mathrm{~cm}^{-3}$. This is $10 \%$ increase of $N_{50}$ over central Europe and $20-40 \%$ over Scandinavia and northwestern Russia.

The addition of IVOC emissions and their aging reactions led to surprising reduction of the total number of particles $\left(N_{t o t}\right)$ and $N_{10}$ by $10-15$ and 5-10\%, respectively, and to an increase of the concentration of $N_{100}$ by 5-10\%. In this case semi-volatile organic mass is produced, which condenses preferentially on particles in the accumulation mode, increasing the condensation and coagulation sinks and leading to a decrease in the concentration of the sub-10 nm particles.

Data and code availability. Field measurement data are available in ebas.nilu.no and https://actris.nilu.no/. The Zeppelin-relevant, San Pietro Capofume and Bologna data are available in https://doi.org/10.5281/zenodo.4660145 (Lampilahti et al. 2021). The field datasets for Patras, Thessaloniki and Costa Navarino can be obtained after request to the authors. The PMCAMx-UF is available from the authors (spyros@ chemeng.upatras.gr).

\section{Supplement.}

Author contributions. DP wrote the code, conducted the simulations, analyzed the results, and wrote the paper. SNP was responsible for the design of the study and the synthesis of the results and contributed to the writing of the paper.

Competing interests. The authors declare that they have no conflict of interest.

Acknowledgments: The authors would like to thank the PEGASOS team and the members and personnel of ACTRIS measurement sites. The ACTRIS project has received funding from the European Union Seventh Framework Programme (ACTRIS, FP7/2007-2013, grant agreement no. 262254) and the ACTRIS-2 project has received funding from the European Union's Horizon 2020 research and innovation programme under grant agreement No 654109. We would like to especially thank: Pasi Aalto, Andres Alastuey, Benjamin Bergmans, Wolfram Birmili, Miroslav Bitter, Raymond Ellul, Markus Fiebig, Harald Flentje, Spiridon Bezantakos, George Biskos, Evangelos Gerasopoulos, Johannes Groess, Bas Henzing, Nikos Kalivitis, Hans Karlsson, Evangelia Kostenidou, Giorgos Kouvarakis, Markku Kulmala, Fabian Lenartz, Gunter Loeschau, Chris Lunder, Nikos Mihalopoulos, Marcel Moerman, David Munao, Colin O'Dowd, Noemi 
Perez, Helena Placha, Jean-Philippe Putaud, Alexander Schladitz, Franz Rohrer, Erik Swietlicki, Ralf Tillmann, Thomas Tuch, Kay Weinhold, Alfred Wiedensohler, Vladimir Zdimal, Hans-

Christen Hansson, Peter Tunved and Radovan Krejci for the results of the field measurementa.

Financial support: This work was supported by the project FORCeS funded from the European Union's Horizon 2020 research and innovation programme under grant agreement No 821205. We also acknowledge support by the project by the Greek PERAN project MIS 5002358.

\section{References}

Adams, P. J. and Seinfeld, J. H.: Predicting global aerosol size distributions in general circulation models, J. Geophys. Res., 107, 4370, https://doi.org/10.1029/2001JD001010, 2002.

Argueso, D., Hidalgo-Munoz, J. M., Gamiz-Fortis, S. R., and Esteban-Parra, M. J.: Evaluation of WRF parameterizations for climate studies over Southern Spain using a multistep regionalization, J. Climate, 24, 5633-5651, 2011.

Atkinson, R.: Atmospheric chemistry of VOCs and $\mathrm{NO}_{\mathrm{x}}$, Atmos. Environ., 34, 2063-2101, 2000.

Atkinson, R. and Arey, J.: Atmospheric degradation of volatile organic compounds, Chem. Rev., 103, 4605-4638, doi:10.1021/cr0206420, 2003.

Carter, W. P. L.: Programs and files implementing the SAPRC-99 mechanism and its associates emissions processing procedures for Models-3 and other regional models, January 31, 2000.

Dahneke, B.: Simple Kinetic Theory of Brownian Diffusion in Va- pors and Aerosols, Theory of Dispersed Multiphase Flow, edited by Meyer, R. E., Academic Press, New York, 97-133 pp., 1983.

Dal Maso, M., Kulmala, M., Riipinen, I., Wagner, R., Hussein, T., Aalto, P., and Lehtinen, K. E. J.: Formation and growth of fresh atmospheric aerosols: eight years of aerosol size distribution data from SMEAR II, Hyytiälä, Finland, Boreal Environ. Res., 10, 323-336, 2005.

de Gouw, J. A., et al.: Budget of organic carbon in a polluted atmosphere: Results from the New England Air Quality Study in 2002, J. Geophys. Res., 110, D16305, doi:10.1029/ 2004JD005623, 2005.

de Meij, A., Gzella, A., Cuvelier, C., Thunis, P., Bessagnet, B., Vinuesa, J. F., Menut, L., and Kelder, H. M.: The im- pact of MM5 and WRF meteorology over complex terrain on CHIMERE model calculations, Atmos. Chem. Phys., 9, 6611- 6632, 2009. 
Denier van der Gon, H. A. C., Visschedijk, A. J. H., Johansson, C., Hedberg Larsson, E., Harrison, R., and Beddows, D.: Size resolved pan European anthropogenic particle number inventory, EUCAARI Deliverable report D141 (available on request from EUCAARI project office), TNO, the Netherlands, 2009.

Docherty, K. S. et al.: Apportionment of Primary and Secondary Organic Aerosols in Southern California during the 2005 Study of Organic Aerosols in Riverside (SOAR-1), Environ. Sci. Technol., 42, 7655-7662, 2008.

Donahue, N. M., Robinson, A. L., Stanier, C. O., Pandis, S. N.: Coupled partitioning, dilution, and chemical aging of semivolatile organics, Environ. Sci. Technol., 40, 2635-2643, 2006.

Donahue, N. M., Epstein, S. A., Pandis, S. N., and Robinson, A. L.: A two-dimensional volatility basis set: 1. organic-aerosol mixing thermodynamics, Atmos. Chem. Phys., 11, 3303-3318, doi:10.5194/acp-11-3303-2011, 2011.

Dzepina, K., Volkamer, R. M., Madronich, S., Tulet, P., Ulbrich, I. M., Zhang, Q., Cappa, C. D., Ziemann, P. J., and Jimenez, J. L.: Evaluation of recently-proposed secondary organic aerosol models for a case study in Mexico City, Atmos. Chem. Phys., 9, 5681-5709, 2009.

Ehn, M., Thornton, J. A., Kleist, E., Sipilä, M., Junninen, H., Pulli- nen, I., Springer, M., Rubach, F., Tillmann, R., Lee, B., Lopez- Hilfiker, F., Andres, S., Acir, I. H., Rissanen, M., Jokinen, T., Schobesberger, S., Kangasluoma, J., Kontkanen, J., Nieminen, T., Kurtén, T., Nielsen, L. B., Jørgensen, S., Kjaergaard, H. G., Canagaratna, M., Dal Maso, M., Berndt, T., Petäjä, T., Wahner, A., Kerminen, V. M., Kulmala, M.,Worsnop, D. R., Wildt, J., and Mentel, T. F.: A large source of low-volatility secondary organic aerosol, Nature, 506, 476-479, 2014.

Environ, User's guide to the comprehensive air quality model with extensions (CAMx), version 4.02, report, ENVIRON Int. Corp., Novato, Calif, 2003.

Fanourgakis, G. S., Kanakidou, M., Nenes, A., Bauer, S. E., Bergman, T., Carslaw, K. S., Grini, A., Hamilton, D. S., Johnson, J. S., Karydis, V. A., Kirkevåg, A., Kodros, J. K., Lohmann, U., Luo, G., Makkonen, R., Matsui, H., Neubauer, D., Pierce, J. R., Schmale, J., Stier, P., Tsigaridis, K., van Noije, T., Wang, H., Watson-Parris, D., Westervelt, D. M., Yang, Y., Yoshioka, M., Daskalakis, N., Decesari, S., Gysel-Beer, M., Kalivitis, N., Liu, X., Mahowald, N. M., Myriokefalitakis, S., Schrödner, R., Sfakianaki, M., Tsimpidi, A. P., Wu, M., and Yu, F.: Evaluation of global simulations of aerosol particle and cloud condensation nuclei number, with implications for cloud droplet formation, Atmos. Chem. Phys., 19, 8591-8617, 2019. 
Fountoukis, C., Riipinen, I., Denier Van Der Gon, H. A. C., Charalampidis, P. E., Pilinis, C., Wiedensohler, A., O’Dowd, C., Putaud, J. P., Moerman, M. and Pandis, S. N.: Simulating ultrafine particle formation in Europe using a regional CTM: Contribution of primary emissions versus secondary formation to aerosol number concentrations, Atmos. Chem. Phys., 12, 8663-8677, 2012.

Garcia-Diez, M., Fernandez, J., Fita, L., and Yague, C.: Sea- sonal dependence of WRF model biases and sensitivity to PBL schemes over Europe, Q. J. Roy. Meteor. Soc., 139, 501-514, 2012.

Gaydos, T. M., Stainer, C. O., and Pandis, S. N.: Modeling of in-situ ultrafine atmospheric particle formation in the eastern United State, J. Geophys. Res., 110, D07S12, https://doi.org/10.1029/ 2004JD004683, 2005.

Gaydos, T., Pinder, R., Koo, B., Fahey, K., Yarwood, G., and Pan- dis, S. N.: Development and application of a three-dimensional Chemical Transport Model, PMCAMx, Atmos. Environ., 41, 2594-2611, 2007.

Gordon, H., Sengupta, K., Rap, A., Duplissy, J., Frege, C., Williamson, C., Heinritzi, M., Simon, M., Yan, C., Almeida, J., Tröstl, J., Nieminen, T., Ortega, I. K., Wagner, R., Dunne, E. M., Adamov, A., Amorim, A., Bernhammer, A.-K., Bianchi, F., Breitenlechner, M., Brilke, S., Chen, X., Craven, J. S., Dias, A., Ehrhart, S., Fischer, L., Flagan, R. C., Franchin, A., Fuchs, C., Guida, R., Hakala, J., Hoyle, C. R., Jokinen, T., Junninen, H., Kangasluoma, J., Kim, J., Kirkby, J., Krapf, M., Kürten, A., Laaksonen, A., Lehtipalo, K., Makhmutov, V., Mathot, S., Molteni, U., Monks, S. A., Onnela, A., Peräkylä, O., Piel, F., Petäjä, T., Praplan, A. P., Pringle, K. J., Richards, N. A. D., Rissanen, M. P., Rondo, L., Sarnela, N., Schobesberger, S., Scott, C. E., Seinfeld, J. H., Sharma, S., Sipilä, M., Steiner, G., Stozhkov, Y., Stratmann, F., Tomé, A., Virtanen, A., Vogel, A. L., Wagner, A. C., Wagner, P. E., Weingartner, E., Wimmer, D., Winkler, P. M., Ye, P., Zhang, X., Hansel, A., Dom- men, J., Donahue, N. M., Worsnop, D. R., Baltensperger, U., Kulmala, M., Curtius, J., and Carslaw, K. S.: Reduced anthropogenic aerosol radiative forcing caused by biogenic new particle formation, P. Natl. Acad. Sci. USA, 113, 12053-12058, 2016.

Guenther, A., Karl, T., Harley, P., Wiedinmyer, C., Palmer, P. I., and Geron, C.: Estimates of global terrestrial isoprene emissions using MEGAN (Model of Emissions of Gases and Aerosols from Nature), Atmos. Chem. Phys., 6, 3181-3210, 2006. 
Hallquist, M., Wenger, J. C., Baltensperger, U., Rudich, Y., Simpson, D., Claeys, M., Dommen, J., Donahue, N. M., George, C., Goldstein, a. H., Hamilton, J. F., Herrmann, H., Hoffmann, T., Iinuma, Y., Jang, M., Jenkin, M. E., Jimenez, J. L., Kiendler-Scharr, a., Maenhaut, W., McFiggans, G., Mentel, T. F., Monod, A., Prévôt, A. S. H., Seinfeld, J. H., Surratt, J. D., Szmigielski, R. and Wildt, J.: The formation, properties and impact of secondary organic aerosol: current and emerging issues, Atmos. Chem. Phys., 9, 5155-5236, 2009.

Hamed, A., Joutsensaari, J., Mikkonen, S., Sogacheva, L., Dal Maso, M., Kulmala, M., Cavalli, F., Fuzzi, S., Facchini, M. C., Decesari, S., Mircea, M., Lehtinen, K. E. J., and Laaksonen, A.: Nucleation and growth of new particles in Po Valley, Italy, Atmos. Chem. Phys., 7, 355-376, 2007.

Im, U., Markakis, K., Unal, A., Kindap, T., Poupkou, A., Incecik, S., Yenigun, O., Melas, D., Theodosi, C., and Mihalopoulos, N.: Study of a winter PM episode in Istanbul using the high resolution WRF/CMAQ modeling system, Atmos. Environ., 44, 3085-3094, 2010.

Jimenez-Guerrero, P., Jorba, O., Baldasano, J. M., and Gasso, S.: The use of a modelling system as a tool for air quality management: Annual high-resolution simulations and evaluation, Sci. Total Environ., 390, 323-340, 2008.

Jokinen, T., Berndt, T., Makkonen, R., Kerminen, V.-M., Jun- ninen, H., Paasonen, P., Stratmann, F., Herrmann, H., Guenther, A. B., Worsnop, D. R., Kulmala, M., Ehn, M., and Sipilä, M.: Production of extremely low volatile organic com- pounds from biogenic emissions: Measured yields and atmospheric implications, P. Natl. Acad. Sci. USA, 112, 7123-7128, 2015.

Jung, J., Adams, P. J., and Pandis, S. N.: Simulating the size distribution and chemical composition of ultrafine particles during nucleation events, Atmos. Environ., 40, 2248-2259, 2006.

Jung, J. G., Fountoukis, C., Adams, P. J. and Pandis, S. N.: Simulation of in situ ultrafine particle formation in the eastern United States using PMCAMx-UF, J. Geophys. Res., 115, D03203, doi: 10.1029/2009jd012313, 2010.

Kanakidou, M., Seinfeld, J. H., Pandis, S. N., Barnes, I., Dentener, F. J., Facchini, M. C., Van Dingenen, R., Ervens, B., Nenes, A., Nielsen, C. J., Swietlicki, E., Putaud, J. P., Balkanski, Y., Fuzzi, S., Horth, J., Moortgat, G. K., Winterhalter, R., Myhre, C. E. L., Tsigaridis, K., Vignati, E., Stephanou, E. G., and Wilson, J.: Organic aerosol and global climate modelling: a review, Atmos. Chem. Phys., 5, 1053-1123, 2005. 
Karydis, V. A., Tsimpidi, A. P., and Pandis, S. N.: Evaluation of a three-dimensional chemical transport model (PMCAMx) in the eastern United States for all four seasons, J. Geophys. Res., 112, D14211, https://doi.org/10.1029/2006JD007890, 2007.

Kirkby, J., Duplissy, J., Sengupta, K., Frege, C., Gordon, H., Williamson, C., Heinritzi, M., Simon, M., Yan, C., Almeida, J., Tröstl, J., Nieminen, T., Ortega, I. K., Wagner, R., Adamov, A., Amorim, A., Bernhammer, A.-K., Bianchi, F., Breitenlechner, M., Brilke, S., Chen, X., Craven, J., Dias, A., Ehrhart, S., Flagan, R. C., Franchin, A., Fuchs, C., Guida, R., Hakala, J., Hoyle, C. R., Jokinen, T., Junninen, H., Kangasluoma, J., Kim, J., Krapf, M., Kürten, A., Laaksonen, A., Lehtipalo, K., Makhmutov, V., Mathot, S., Molteni, U., Onnela, A., Peräkylä, O., Piel, F., Petäjä, T., Praplan, A. P., Pringle, K., Rap, A., Richards, N. A. D., Riip- inen, I., Rissanen, M. P., Rondo, L., Sarnela, N., Schobesberger, S., Scott, C. E., Seinfeld, J. H., Sipilä, M., Steiner, G., Stozhkov, Y., Stratmann, F., Tomé, A., Virtanen, A., Vogel, A. L., Wag- ner, A. C., Wagner, P. E., Weingartner, E., Wimmer, D., Winkler, P. M., Ye, P., Zhang, X., Hansel, A., Dommen, J., Donahue, N. M., Worsnop, D. R., Baltensperger, U., Kulmala, M., Carslaw, K. S., and Curtius, J.: Ion-induced nucleation of pure biogenic particles, Nature, 533, 521-526, https://doi.org/10.1038/nature17953, 2016.

Kleinman, L. I., Springston, S. R., Daum, P. H., Lee, Y.-N., Nunnermacker, L. J., Senum, G. I., Wang, J., Weinstein-Lloyd, J., Alexander, M. L., Hubbe, J., Ortega, J., Canagaratna, M. R., and Jayne, J.: The time evolution of aerosol composition over the Mexico City plateau, Atmos. Chem. Phys., 8, 1559-1575, doi:10.5194/acp-8-1559-2008, 2008.

Kostenidou, E., Florou, K., Kaltsonoudis, C., Tsiflikiotou, M., Vratolis, S., Eleftheriadis, K., and Pandis, S. N.: Sources and chemical characterization of organic aerosol during the summer in the eastern Mediterranean, Atmos. Chem. Phys., 15, 11355-11371, 2015.

Kroll, J. H., Ng, N. L., Murphy, S. M., Flagan, R. C., Seinfeld, J. H.: Secondary organic aerosol formation from isoprene photooxidation, Environ. Sci. Technol., 40, 155-162, 2006.

Kulmala, M., Vehkamaki, H., Petaja, T., Dal Maso, M., Lauri, A., Kerminen, V.-M., Birmili, W., and McMurry, P. H.: Formation and growth of ultrafine atmospheric particles: A review of observations, J. Aerosol Sci., 35, 143-176, 2004.

Kulmala, M., Asmi, A., Lappalainen, H. K., Baltensperger, U., Brenguier, J.-L., Facchini, M. C., Hansson, H.-C., Hov, Ø., O’Dowd, C. D., Pöschl, U., Wiedensohler, A., Boers, R.,Ammann, M., Arabas, S., Artaxo, P., Baars, H., Beddows, D. C. S., Bergström, R., Beukes, J. P., Bilde, 
M., Burkhart, J. F., Canonaco, F., Clegg, S. L., Coe, H., Crumeyrolle, S., D’Anna, B., Decesari, S., Gilardoni, S., Fischer, M., Fjaeraa, A. M., Fountoukis, C., George, C., Gomes, L., Halloran, P., Hamburger, T., Harrison, R. M., Herrmann, H., Hoffmann, T., Hoose, C., Hu, M., Hyvärinen, A., Hõrrak, U., Iinuma, Y., Iversen, T., Josipovic, M., Kanakidou, M., KiendlerScharr, A., Kirkevåg, A., Kiss, G., Klimont, Z., Kolmonen, P., Komppula, M., Kristjánsson, J.-E., Laakso, L., Laaksonen, A., Labonnote, L., Lanz, V. A., Lehtinen, K. E. J., Rizzo, L. V., Makkonen, R., Manninen, H. E., McMeeking, G., Merikanto, J., Minikin, A., Mirme, S., Morgan, W. T., Nemitz, E., O’Donnell, D., Panwar, T. S., Pawlowska, H., Petzold, A., Pienaar, J. J., Pio, C., Plass-Duelmer, C., Prévôt, A. S. H., Pryor, S., Reddington, C. L., Roberts, G., Rosen- feld, D., Schwarz, J., Seland, Ø., Sellegri, K., Shen, X. J., Shiraiwa, M., Siebert, H., Sierau, B., Simpson, D., Sun, J. Y., Topping, D., Tunved, P., Vaattovaara, P., Vakkari, V., Veefkind, J. P., Visschedijk, A., Vuollekoski, H., Vuolo, R., Wehner, B., Wildt, J., Woodward, S., Worsnop, D. R., van Zadelhoff, G.- J., Zardini, A. A., Zhang, K., van Zyl, P. G., Kerminen, V.- M., S Carslaw, K., and Pandis, S. N.: General overview: Euro- pean Integrated project on Aerosol Cloud Climate and Air Quality interactions (EUCAARI) - integrating aerosol research from nano to global scales, Atmos. Chem. Phys., 11, 13061-13143, https://doi.org/10.5194/acp-11-13061-2011, 2011.

Lampilahti, J., Manninen, H. E., Nieminen, T., Mirme, S., Ehn, M., Pullinen, I., Leino, K., Schobesberger, S., Kangasluoma, J., Kontkanen, J., Järvinen, E., Väänänen, R., Yli-Juuti, T., Krejci, R., Lehtipalo, K., Levula, J., Mirme, A., Decesari, S., Tillmann, R., Worsnop, D. R., Rohrer, F., Kiendler-Scharr, A., Petäjä, T., Kerminen, V.-M., Mentel, T. F., and Kulmala, M.: Zeppelin-led study on the onset of new particle formation in the planetary boundary layer, Atmos. Chem. Phys. Discuss. [preprint], https://doi.org/10.5194/acp-2021-282, in review, 2021.

Lane, T. E., Donahue, N. M., and Pandis, S. N.: Simulating secondary organic aerosol formation using the volatility basis-set approach in a chemical transport model, Atmos. Environ., 42, 7439-7451, 2008.

Makkonen, R., Asmi, A., Korhonen, H., Kokkola, H., Järvenoja, S., Räisänen, P., Lehtinen, K. E. J., Laaksonen, A., Kerminen, V.- M., Järvinen, H., Lohmann, U., Bennartz, R., Feichter, J., and Kulmala, M.: Sensitivity of aerosol concentrations and cloud properties to nucleation and 
secondary organic distribution in ECHAM5-HAM global circulation model, Atmos. Chem. Phys., 9, 1747-1766, https://doi.org/10.5194/acp-9-1747-2009, 2009.

713

714

715

716

Mann, G. W., Carlslaw, K. S., Spracklen, D. V., Ridley, D. A., Manketelow, P. T., Chipperfield, M. P., Pickering, S. J., and Johnson, C. E.: Description and evaluation of GLOMAP-mode: A modal global aerosol microphysics model for the UKCA composition-climate model. Geosci. Model Dev., 3, 519-551, 2010.

Matsui, H., et al.: Secondary organic aerosol formation in urban air: Temporal variations and possible contributions from unidentified hydrocarbons, J. Geophys. Res., 114, D04201, doi:10.1029/2008JD010164, 2009.

Merikanto, J., Spracklen, D. V., Mann, G. W., Pickering, S. J., and Carslaw, K. S.: Impact of nucleation on global CCN, Atmos. Chem. Phys., 9, 8601-8616, https://doi.org/10.5194/acp-98601- 2009, 2009.

Murphy, B. N., Pandis, S. N. and Ave, F.: Simulating the formation of semivolatile primary and secondary organic aerosol in a regional chemical transport model gas-phase chemistry of OA species, Environ. Sci. Technol., 43, 4722-4728, 2009.

Napari, I., Noppel, M., Vehkamaki, H., and Kulmala, M.: Parameterization of ternary nucleation rates for H2SO4-NH3- H2O vapors, J. Geophys. Res., 107, AAC 6-1-AAC 6-6, https://doi.org/10.1029/2002JD002132, 2002.

Ng, N. L., Kroll, J. H., Keywood, M. D., Bahreini, R., Varutbangkul, V., Flagan, R. C., Seinfeld, J. H.: Contribution of first- versus second-generation products to secondary organic aerosols formed in the oxidation of biogenic hydrocarbons, Environ. Sci. Technol., 40, 2283-2297, 2006

Odum, J. R., Hoffmann, T., Bowman, F. A., Collins, D., Flagan, R. C., Seinfeld, J. H.: Gas/particle partitioning and secondary organic aerosol yields, Environ. Sci. Technol., 30, 2580-2585, 1996.

O’Dowd, C. D., Langmann, B., Varghese, S., Scannell, C., Ceburnis, D., and Facchini, M. C.: A combined organic-inorganic sea-spray source function, Geophys. Res. Lett., 35, L01801, https://doi.org/10.1029/2007GL030331, 2008.

Olenius, T., Yli-Juuti, T., Elm, J, Kontkanen, J., and Riipinen I. New particle formation and growth: creating a new atmospheric phase interface. In Physical Chemistry of Gas-Liquid Interfaces (eds. Faust, J. A. \& House, J. E.), 315-352, Elsevier, 2018. 
Pathak, R. K., Presto, A. A., Lane, T. E., Stanier, C. O., Donahue, N. M., Pandis, S. N.: Ozonolysis of $\alpha$-pinene: parameterization of secondary organic aerosol mass fraction, Atmos. Chem. Phys., 7, 3811-3821, 2007.

Patoulias, D., Fountoukis, C., Riipinen, I., and Pandis, S. N.: The role of organic condensation on ultrafine particle growth during nucleation events, Atmos. Chem. Phys., 15, 6337-6350, https://doi.org/10.5194/acp-15-6337-2015, 2015.

Patoulias, D., Fountoukis, C., Riipinen, I., Asmi, A., Kulmala, M., and Pandis, S. N.: Simulation of the size-composition distribution of atmospheric nanoparticles over Europe, Atmos. Chem. Phys., 18, 13639-13654, https://doi.org/10.5194/acp-18-13639-2018, 2018.

Pierce, J. R. and Adams, P. J.: A computationally efficient aerosol nucleation/condensation method: Pseudo-steady state sulfuric acid, Aerosol Sci. Tech., 43, 216-226, 2009

Pierce, J. R., Riipinen, I., Kulmala, M., Ehn, M., Petäjä, T., Junninen, H., Worsnop, D. R., and Donahue, N. M.: Quantification of the volatility of secondary organic compounds in ultrafine particles during nucleation events, Atmos. Chem. Phys., 11, 9019-9036, https://doi.org/10.5194/acp-11-9019-2011, 2011.

Presto, A. A., Donahue, N. M.: Investigation of a-pinene+ozone secondary organic aerosol formation at low total aerosol mass. Environ. Sci. Technol., 40, 3536-3543, 2006.

Rissanen, M. P., Kurtén, T., Sipilä, M., Thornton, J. A., Kangasluoma, J., Sarnela, N., Junninen, H., Jørgensen, S., Schallhart, S., Kajos, M. K., Taipale, R., Springer, M., Mentel, T. F., Ruuskanen, T., Petäjä, T., Worsnop, D. R., Kjaergaard, H. G., and Ehn, M.: The formation of highly oxidized multifunctional products in the ozonolysis of cyclohexene, J. Am. Chem. Soc., 136, 15596-15606, 2014.

Robinson, A. L., Donahue, N. M., Shrivastava, M. K., Weitkamp, E. A., Sage, A. M., Grieshop, A. P., Lane, T. E., Pandis, S. N., Pierce, J. R.: Rethinking organic aerosols: semivolatile emissions and photochemical aging, Science, 315, 1259-1262, 2007.

Schulze, B. C., Wallace, H. W., Flynn, J. H., Lefer, B. L., Erickson, M. H., Jobson, B. T., Dusanter, S., Griffith, S. M., Hansen, R. F., Stevens, P. S., VanReken, T., and Griffin, R. J.: Differences in BVOC oxidation and SOA formation above and below the forest canopy, Atmos. Chem. Phys., 17, 1805-1828, https://doi.org/10.5194/acp-17-1805-2017, 2017.

Seinfeld, J. H.; Pandis S. N. Atmospheric Chemistry and Physics: From Air Pollution to Climate Change, 2nd ed.; John Wiley and Sons, Hoboken, NJ, 2006. 
Sengupta, K., Pringle, K., Johnson, J. S., Reddington, C., Browse, J., Scott, C. E., and Carslaw, K.: A global model perturbed parameter ensemble study of secondary organic aerosol formation, Atmos. Chem. Phys., 21, 2693-2723, https://doi.org/10.5194/acp-21-2693-2021, 2021.

Shrivastava, M. K., Lane, T. E., Donahue, N. M., Pandis, S. N., and Robinson, A. L.: Effects of gas-particle partitioning and aging of primary emissions on urban and regional organic aerosol concentrations, J. Geophys. Res., 113, D18301, doi:10.1029/2007JD009735, 2008.

Shrivastava, M., Thornton, J., Cappa, C., Fan, J., Goldstein, A., Guenther, A., Jimenez, J. L., Kuang, C., Laskin, A., Martin, S., Ng, N. L., Petaja, T., Pierce, J., Rasch, P., Roldin, P., Seinfeld, J., Shilling, J., Smith, J., Volkamer, R., Wang, J., Worsnop, D., Zaveri, R., Zelenyuk, A., and Zhang, Q.: Recent advances in understanding secondary organic aerosols: implications for global climate forcing, Rev. Geophys., 55, 509-559, 2017.

Skamarock, W. C., Klemp, J. B., Dudhia, J., Gill, D. O., Barker, D. M., Wang, W., and Powers, J. G.: A Description of the Advanced Research WRF Version 2, NCAR Technical Note, available at: http://www2.mmm.ucar.edu/wrf/users/docs/arw_v2_070111.pdf (last access: 12 September 2018), 2005.

Sofiev, M., Vankevich, R., Lanne, M., Koskinen, J., and Kukkonen, J.: On integration of a Fire Assimilation System and a chemical transport model for near-real-time monitoring of the impact of wild-land fires on atmospheric composition and air quality, Modelling, Monitoring and Management of Forest Fires, WIT Trans. Ecol. Envir., 119, 343-351, 2008 a.

Sofiev, M., Lanne, M., Vankevich, R., Prank, M., Karppinen, A., and Kukkonen, J.: Impact of wild-land fires on European air quality in 2006-2008, Modelling, Monitoring and Management of Forest Fires, WIT Trans. Ecol. Envir., 119, 353-361, 2008b.

Sogacheva, L., Hamed, A., Facchini, M. C., Kulmala, M., and Laaksonen, A.: Relation of air mass history to nucleation events in Po Valley, Italy, using back trajectories analysis, Atmos. Chem. Phys., 7, 839-853, https://doi.org/10.5194/acp-7-839-2007, 2007.

Spracklen, D. V., Pringle, K. J., Carslaw, K. S., Chipperfield, M. P., and Mann, G. W.: A global off-line model of size- resolved aerosol microphysics: I. Model development and pre- diction of aerosol properties, Atmos. Chem. Phys., 5, 2227- 2252, doi:10.5194/acp-5-2227-2005, 2005 . 
Stanier, C. O., Pathak, R. K. and Pandis, S. N.: Measurements of the volatility of aerosols from apinene ozonolysis, Environ. Sci. Technol., 41, 2756-2763, 2007.

Vehkamäki, H., Kulmala, M., Napari, I., Lehtinen, K. E. J., Timm- reck, C., Noppel, M., and Laaksonen, A.: An improved parameterization for sulfuric acid-water nucleation rates for tropospheric and stratospheric conditions, J. Geophys. Res., 107, 4622-4632, 2002.

Visschedijk, A. J. H., Zandveld, P., and Denier van der Gon, H. A. C.: TNO Report 2007 AR0233/B: A high resolution gridded European emission database for the EU integrated project GEMS, Organization for Applied Scientific Research, the Netherlands, 2007.

Volkamer, R., Jimenez, J. L., San Martini, F., et al.: Secondary organic aerosol formation from anthropogenic air pollution: Rapid and higher than expected, Geophys. Res. Lett., 33, L17811, doi:10.1029/2006GL026899, 2006.

Wang, M. and Penner, J. E.: Aerosol indirect forcing in a global model with particle nucleation, Atmos. Chem. Phys., 9, 239-260, https://doi.org/10.5194/acp-9-239-2009, 2009.

Yli-Juuti, T., Mohr, C., and Riipinen, I. Open questions on atmospheric nanoparticle growth. Commun. Chem. 3, 106, https://doi.org/10.1038/s42004-020-00339-4, 2020.

Yu, F. and Luo, G.: Simulation of particle size distribution with a global aerosol model: contribution of nucleation to aerosol and CCN number concentrations, Atmos. Chem. Phys., 9, 7691-7710, doi:10.5194/acp-9-7691-2009, 2009.

Zhang, Q., Jimenez, J. L., Canagaratna, M. R., Allan, J. D., Coe, H., Ulbrich, I., Alfarra, M. R., Takami, A., Middlebrook, A. M., Sun, Y. L., Dzepina, K., Dunlea, E., Docherty, K., DeCarlo, P. F., Salcedo, D., Onasch, T., Jayne, J. T., Miyoshi, T., Shimono, A., Hatakeyama, S., Takegawa, N., Kondo, Y., Schneider, J., Drewnick, F., Borrmann, S., Weimer, S., Demerjian, K., Williams, P., Bower, K., Bahreini, R., Cottrell, L., Griffin, R. J., Rautiainen, J., Sun, J. Y., Zhang, Y. M., and Worsnop, D. R.: Ubiquity and dominance of oxygenated species in organic aerosols in anthropogenically-influenced Northern Hemisphere midlatitudes, Geophys. Res. Lett., 34, L13801, doi:10.1029/2007GL029979, 2007. 
Table 1: Prediction skill metrics of PMCAMx-UF against daily ground measurements of particle number concentration above $10 \mathrm{~nm}\left(N_{10}\right)$ during 5 June -8 July 2012.

832

\begin{tabular}{|c|c|c|c|c|c|c|c|}
\hline \multirow[t]{2}{*}{ Station } & \multirow{2}{*}{$\begin{array}{c}\text { Mean } \\
\text { Observed } \\
\left(\mathrm{cm}^{-3}\right) \\
\end{array}$} & \multicolumn{2}{|c|}{$\begin{array}{l}\text { Mean Predicted } \\
\left(\mathrm{cm}^{-3}\right)\end{array}$} & \multicolumn{2}{|c|}{ NMB (\%) } & \multicolumn{2}{|c|}{ NME(\%) } \\
\hline & & Base case & $\begin{array}{l}\text { Without } \\
\text { ELVOCs }\end{array}$ & Base case & $\begin{array}{r}\text { Without } \\
\text { ELVOCs }\end{array}$ & $\begin{array}{l}\text { Base } \\
\text { case }\end{array}$ & $\begin{array}{l}\text { Without } \\
\text { ELVOCs }\end{array}$ \\
\hline \multicolumn{8}{|c|}{$N_{10}$} \\
\hline ANB & 8057 & 6617 & 6585 & -18 & -18 & 39 & 39 \\
\hline ASP & 2130 & 5233 & 5202 & 146 & 144 & 144 & 144 \\
\hline BRK & 1878 & 3144 & 3053 & 67 & 63 & 86 & 86 \\
\hline CBW & 13101 & 9913 & 9817 & -24 & -25 & 31 & 31 \\
\hline DSN & 10591 & 6508 & 6504 & -39 & -39 & 41 & 41 \\
\hline DSW & 7706 & 6111 & 6091 & -21 & -21 & 40 & 40 \\
\hline FNK & 3962 & 5466 & 5466 & 38 & 38 & 40 & 40 \\
\hline GDN & 5712 & 6652 & 6731 & 16 & 18 & 32 & 32 \\
\hline $\mathrm{HOH}$ & 3438 & 3070 & 2906 & -11 & -15 & 38 & 38 \\
\hline HYY & 2207 & 2536 & 2265 & 15 & 3 & 31 & 31 \\
\hline ISP & 6232 & 6449 & 6203 & 3 & 0 & 43 & 43 \\
\hline $\mathrm{KPU}$ & 5269 & 5855 & 5937 & 11 & 13 & 43 & 43 \\
\hline KST & 3596 & 4881 & 4834 & 36 & 34 & 46 & 46 \\
\hline MLP & 5583 & 6034 & 6003 & 8 & 8 & 42 & 42 \\
\hline MNT & 6455 & 8364 & 8273 & 30 & 28 & 45 & 45 \\
\hline PRG & 7272 & 7281 & 7273 & 0 & 0 & 44 & 44 \\
\hline USM & 15171 & 8335 & 8413 & -45 & -45 & 52 & 52 \\
\hline VAV & 3250 & 8291 & 8283 & 155 & 155 & 155 & 155 \\
\hline VRR & 1107 & 1491 & 1190 & 35 & 7 & 69 & 57 \\
\hline VSM & 2903 & 7281 & 7011 & 151 & 141 & 151 & 141 \\
\hline WLD & 4956 & 7903 & 7783 & 59 & 57 & 66 & 64 \\
\hline ZUG & 1237 & 2405 & 2287 & 94 & 85 & 111 & 103 \\
\hline NEO & 2864 & 5085 & 5039 & 78 & 76 & 79 & 78 \\
\hline PAT & 4705 & 5151 & 5148 & 9 & 9 & 45 & 44 \\
\hline SPC & 8301 & 7198 & 7180 & -13 & -14 & 35 & 35 \\
\hline THE & 3894 & 8577 & 8530 & 120 & 119 & 120 & 119 \\
\hline ALL & 4820 & 5957 & 5889 & 23 & 22 & 63 & 63 \\
\hline
\end{tabular}


837 Table 2: Prediction skill metrics of PMCAMx-UF against daily ground measurements of particle number concentration above $100 \mathrm{~nm}\left(N_{100}\right)$ during 5 June - 8 July 2012.

839

\begin{tabular}{|c|c|c|c|c|c|c|c|}
\hline \multirow[t]{2}{*}{ Station } & \multirow{2}{*}{$\begin{array}{c}\text { Mean } \\
\text { Observed } \\
\left(\mathrm{cm}^{-3}\right) \\
\end{array}$} & \multicolumn{2}{|c|}{$\begin{array}{l}\text { Mean Predicted } \\
\left(\mathrm{cm}^{-3}\right)\end{array}$} & \multicolumn{2}{|c|}{ NMB (\%) } & \multicolumn{2}{|c|}{ NME(\%) } \\
\hline & & Base case & $\begin{array}{l}\text { Without } \\
\text { ELVOCs }\end{array}$ & Base case & $\begin{array}{l}\text { Without } \\
\text { ELVOCs }\end{array}$ & $\begin{array}{l}\text { Base } \\
\text { case }\end{array}$ & $\begin{array}{l}\text { Without } \\
\text { ELVOCs }\end{array}$ \\
\hline \multicolumn{8}{|c|}{$N_{100}$} \\
\hline ANB & 1518 & 939 & 934 & -38 & -38 & 47 & 47 \\
\hline ASP & 552 & 789 & 694 & 43 & 26 & 61 & 51 \\
\hline BRK & 607 & 419 & 397 & -31 & -35 & 65 & 62 \\
\hline CBW & 1627 & 1550 & 1441 & -5 & -11 & 18 & 16 \\
\hline DSN & 1976 & 1178 & 1052 & -40 & -47 & 44 & 49 \\
\hline DSW & 1426 & 1156 & 1050 & -19 & -26 & 35 & 37 \\
\hline FNK & 1760 & 2383 & 2330 & 35 & 32 & 39 & 36 \\
\hline GDN & 2492 & 2797 & 2826 & 12 & 13 & 34 & 33 \\
\hline $\mathrm{HOH}$ & 1011 & 697 & 656 & -31 & -35 & 37 & 40 \\
\hline HYY & 677 & 579 & 445 & -14 & -34 & 26 & 38 \\
\hline ISP & 1775 & 1334 & 1283 & -25 & -28 & 37 & 38 \\
\hline KPU & 1543 & 1898 & 1861 & 23 & 21 & 29 & 28 \\
\hline KST & 1123 & 1138 & 1061 & 1 & -6 & 26 & 21 \\
\hline MLP & 1214 & 1111 & 977 & -9 & -20 & 30 & 33 \\
\hline MNT & 1492 & 1871 & 1799 & 25 & 21 & 49 & 50 \\
\hline PRG & 1177 & 1256 & 1167 & 7 & -1 & 26 & 25 \\
\hline USM & 1657 & 1091 & 985 & -34 & -41 & 40 & 44 \\
\hline VAV & 766 & 942 & 899 & 23 & 17 & 48 & 48 \\
\hline VRR & 324 & 166 & 90 & -49 & -72 & 63 & 77 \\
\hline VSM & 704 & 747 & 643 & 6 & -9 & 34 & 34 \\
\hline WLD & 1116 & 1063 & 955 & -5 & -14 & 20 & 23 \\
\hline ZUG & 555 & 555 & 546 & 0 & -2 & 44 & 44 \\
\hline NEO & 1489 & 2041 & 1971 & 37 & 32 & 45 & 42 \\
\hline PAT & 1747 & 1765 & 1766 & 1 & 1 & 21 & 23 \\
\hline SPC & 1702 & 2051 & 1978 & 21 & 16 & 36 & 36 \\
\hline THE & 1387 & 2420 & 2384 & 74 & 72 & 78 & 76 \\
\hline ALL & 1198 & 1326 & 1258 & 10 & 5 & 45 & 45 \\
\hline
\end{tabular}


Table 3: Predicted (PMCAMx-UF) and observed (AMS) average $\mathrm{PM}_{1}$ concentrations of sulfate, ammonium and nitrate in different locations for base case simulation.

\begin{tabular}{|c|c|c|c|c|c|c|}
\hline \multirow{2}{*}{ Station } & \multicolumn{2}{|c|}{ Sulfate } & \multicolumn{2}{c|}{ Ammonium } & \multicolumn{2}{c|}{ Nitrate } \\
\cline { 2 - 7 } & Predicted & Observed & Predicted & Observed & Predicted & Observed \\
& $\left(\mu \mathrm{g} \mathrm{m}^{-3}\right)$ & $\left(\mu \mathrm{g} \mathrm{m}^{-3}\right)$ & $\left(\mu \mathrm{g} \mathrm{m}^{-3}\right)$ & $\left(\mu \mathrm{g} \mathrm{m}^{-3}\right)$ & $\left(\mu \mathrm{g} \mathrm{m}^{-3}\right)$ & $\left(\mu \mathrm{g} \mathrm{m}^{-3}\right)$ \\
\hline FIN & 4.44 & 3.50 & 1.82 & 1.06 & 1.00 & 0.07 \\
\hline PAT & 2.83 & 3.35 & 1.34 & 0.95 & 0.84 & 0.10 \\
\hline BOL & 2.11 & 2.79 & 1.08 & 1.00 & 0.90 & 0.60 \\
\hline SPC & 2.31 & 1.81 & 1.16 & 0.88 & 0.99 & 1.20 \\
\hline ALL & 2.99 & 2.82 & 1.37 & 0.97 & 0.94 & 0.52 \\
\hline
\end{tabular}

Table 4: Prediction skill metrics of PMCAMx-UF base case simulation against daily $\mathrm{PM}_{1} \mathrm{OA}$ measurements.

\begin{tabular}{|c|c|c|c|c|c|}
\hline Station & $\begin{array}{c}\text { Mean } \\
\text { Predicted } \\
\left(\mu \mathrm{g} \mathrm{m}^{-3}\right)\end{array}$ & $\begin{array}{c}\text { Mean } \\
\text { Observed } \\
\left(\mu \mathrm{g} \mathrm{m}^{-3}\right)\end{array}$ & $\begin{array}{l}\text { NMB } \\
(\%)\end{array}$ & $\begin{array}{l}\text { NME } \\
(\%)\end{array}$ & $\begin{array}{c}\text { Factor of } 2 \\
(\%)\end{array}$ \\
\hline FIN & 3.19 & 2.12 & 50 & 51 & 83 \\
\hline PAT & 2.75 & 3.80 & -28 & 28 & 95 \\
\hline BOL & 4.62 & 5.68 & -19 & 33 & 74 \\
\hline SPC & 4.74 & 3.98 & 19 & 44 & 77 \\
\hline $\mathbf{A L L}$ & 3.87 & 3.79 & 2 & 38 & 82 \\
\hline
\end{tabular}


852 Table 5: Prediction skill metrics of PMCAMx-UF against daily $\mathrm{PM}_{2.5}$ OA measurements.

\begin{tabular}{|c|c|c|c|c|c|c|c|}
\hline \multirow{2}{*}{ Name } & \multirow[t]{2}{*}{ Station } & \multirow[t]{2}{*}{ Country } & \multirow{2}{*}{$\begin{array}{c}\text { Mean } \\
\text { Observed } \\
\left(\mu \mathrm{g} \mathrm{m}^{-3}\right)\end{array}$} & $\begin{array}{c}\text { Mean } \\
\text { Predicted }\end{array}$ & NMB & NME & $\begin{array}{c}\text { Factor of } \\
2 \\
\end{array}$ \\
\hline & & & & $\left(\mu \mathrm{g} \mathrm{m}^{-3}\right)$ & $(\%)$ & $(\%)$ & $(\%)$ \\
\hline $\mathrm{CH} 02$ & Payerne & Switzerland & 2.54 & 2.98 & 17 & 73 & 72 \\
\hline DE44 & Melpitz & Germany & 2.52 & 4.42 & 76 & 88 & 66 \\
\hline ES1778 & Montseny & Spain & 4.52 & 6.28 & 39 & 89 & 59 \\
\hline IT04 & Ispra & Italy & 5.13 & 4.41 & -14 & 46 & 71 \\
\hline PL05 & $\begin{array}{c}\text { Diabla } \\
\text { Gora }\end{array}$ & Poland & 3.64 & 4.22 & 16 & 43 & 84 \\
\hline SI08 & Iskrba & Slovenia & 5.98 & 5.07 & -15 & 33 & 80 \\
\hline ALL & & & 4.06 & 4.56 & 20 & 62 & 72 \\
\hline
\end{tabular}



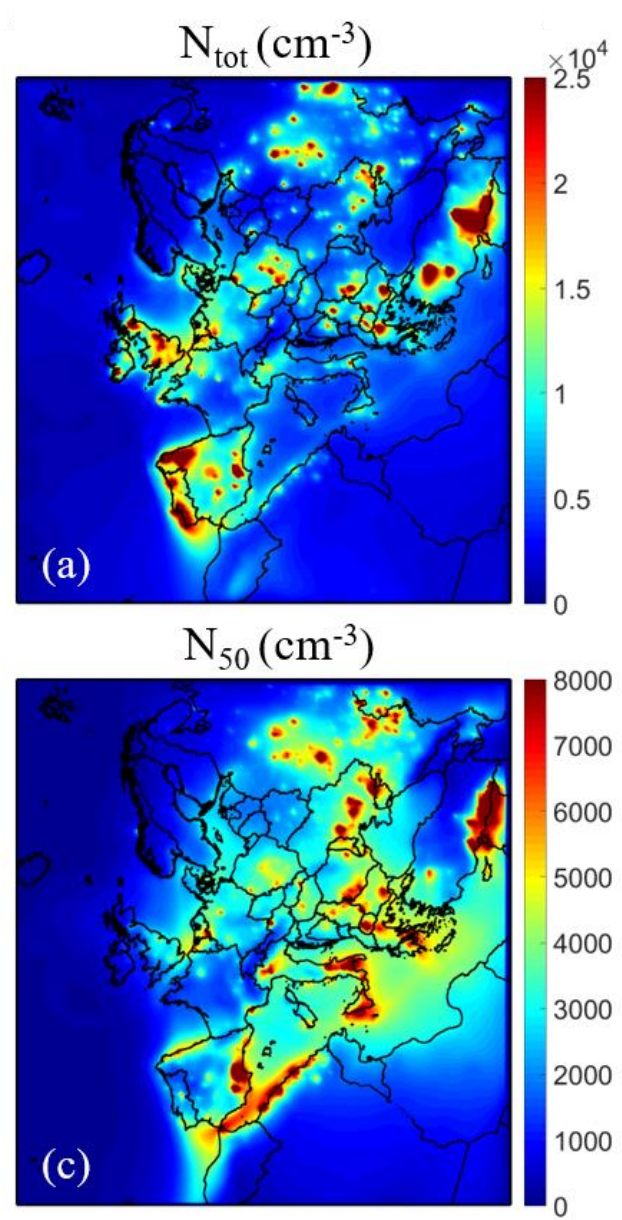

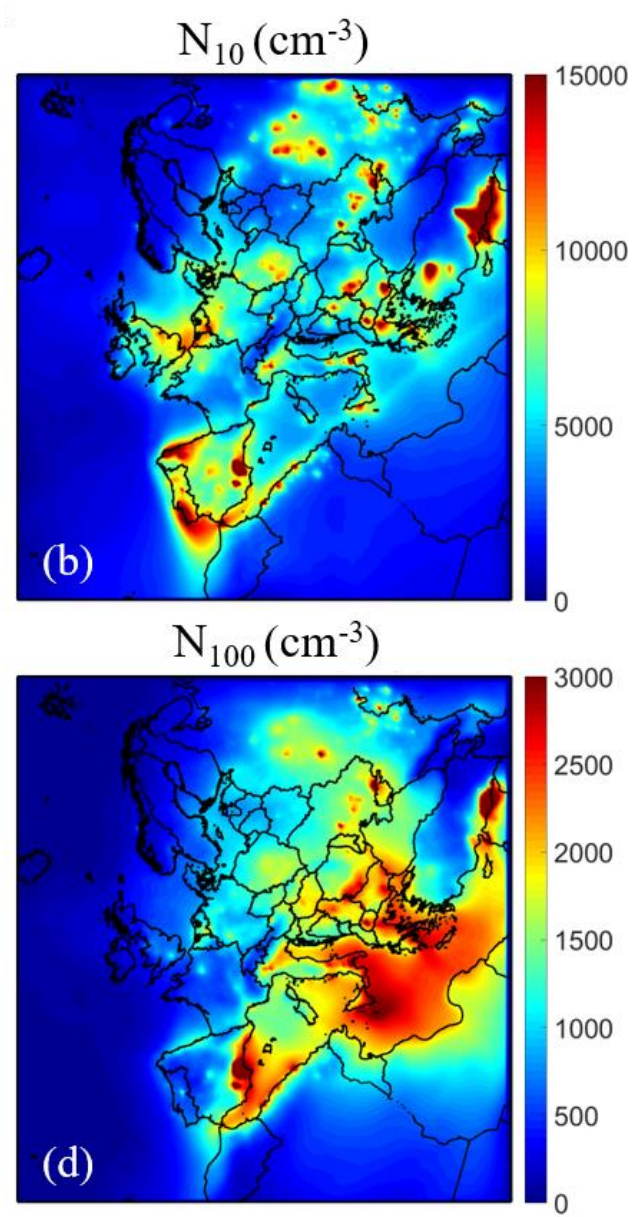

854

855 Figure 1: Average ground level number concentrations $\left(\right.$ in $\mathrm{cm}^{-3}$ ) for the base case simulation 856 during 5 June -8 July 2012 for: (a) all particles $\left(N_{t o t}\right)$; and particles above (b) $10 \mathrm{~nm}\left(N_{l o}\right)$; (c) 50 $857 \mathrm{~nm}\left(N_{50}\right)$; and $(\mathrm{d}) 100 \mathrm{~nm}\left(N_{100}\right)$. Different scales are used. 

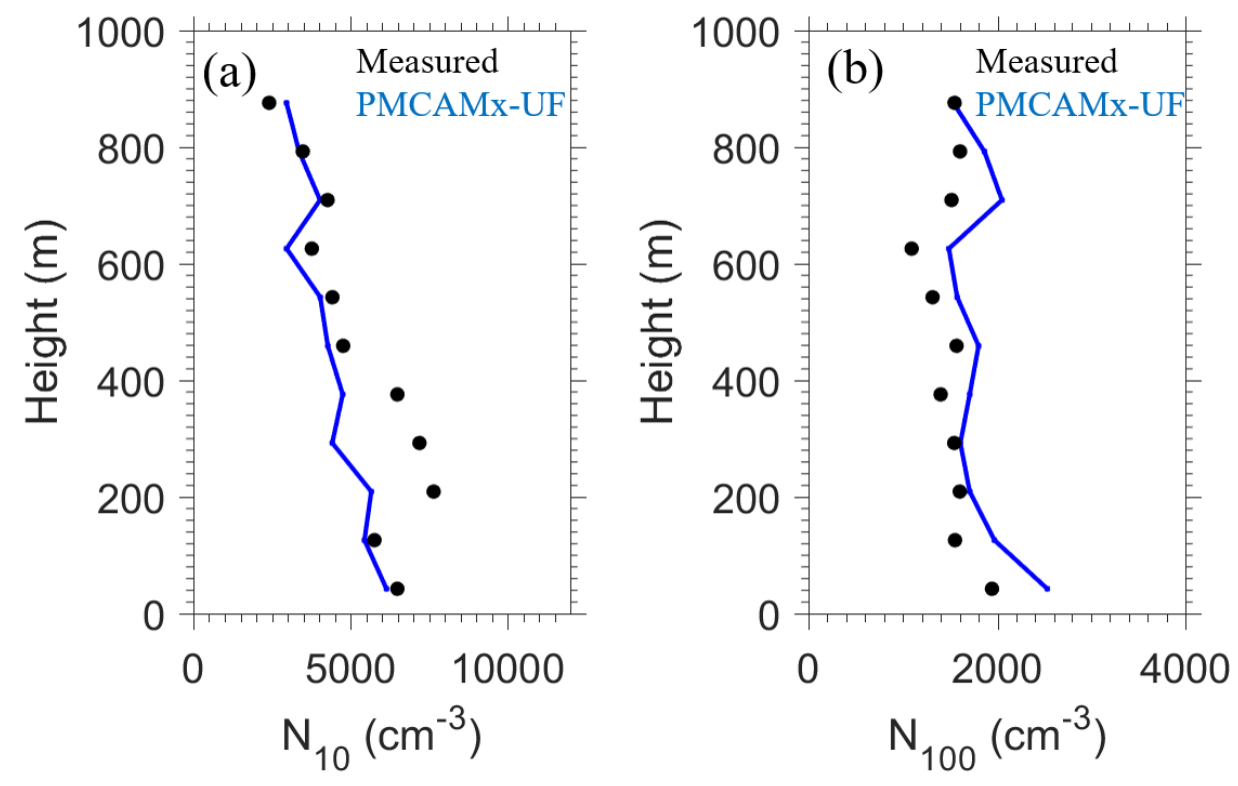

Figure 2: Comparison of predicted PMCAMx-UF (blue line) vs. observed (black dots) vertical 860 profiles of averaged particle number concentrations for (a) $N_{10}$ and (b) $N_{100}$ of 25 flights over the Po Valley during the PEGASOS campaign.

862 


\section{ELVOCs $\mathrm{PM}_{2.5}\left(\mu \mathrm{g} \mathrm{m}^{-3}\right)$}

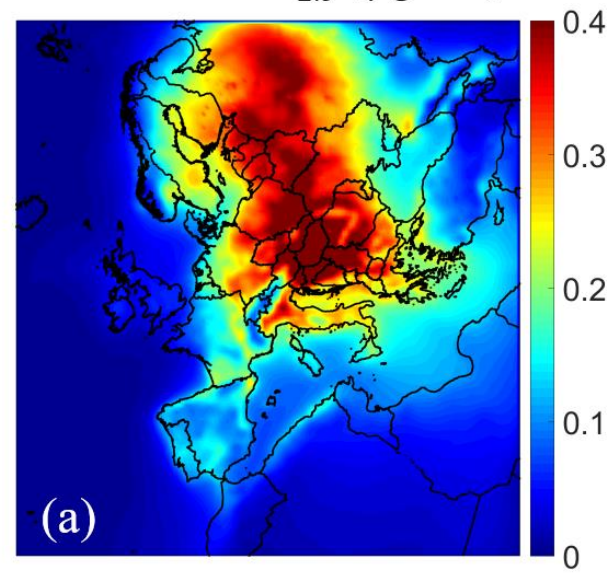

ELVOCs/OA PM 2.5

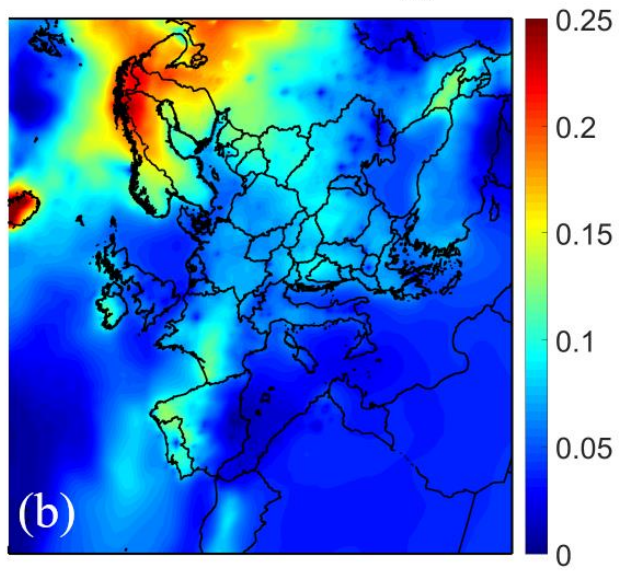

864

865 Figure 3: Average ground level (a) $\mathrm{PM}_{2.5}$ ELVOCs mass concentration (in $\mu \mathrm{g} \mathrm{m}^{-3}$ ) and (b) the 866 ratio of the $\mathrm{PM}_{2.5}$ mass of ELVOCs to OA during the simulation. Different scales are used.

867 

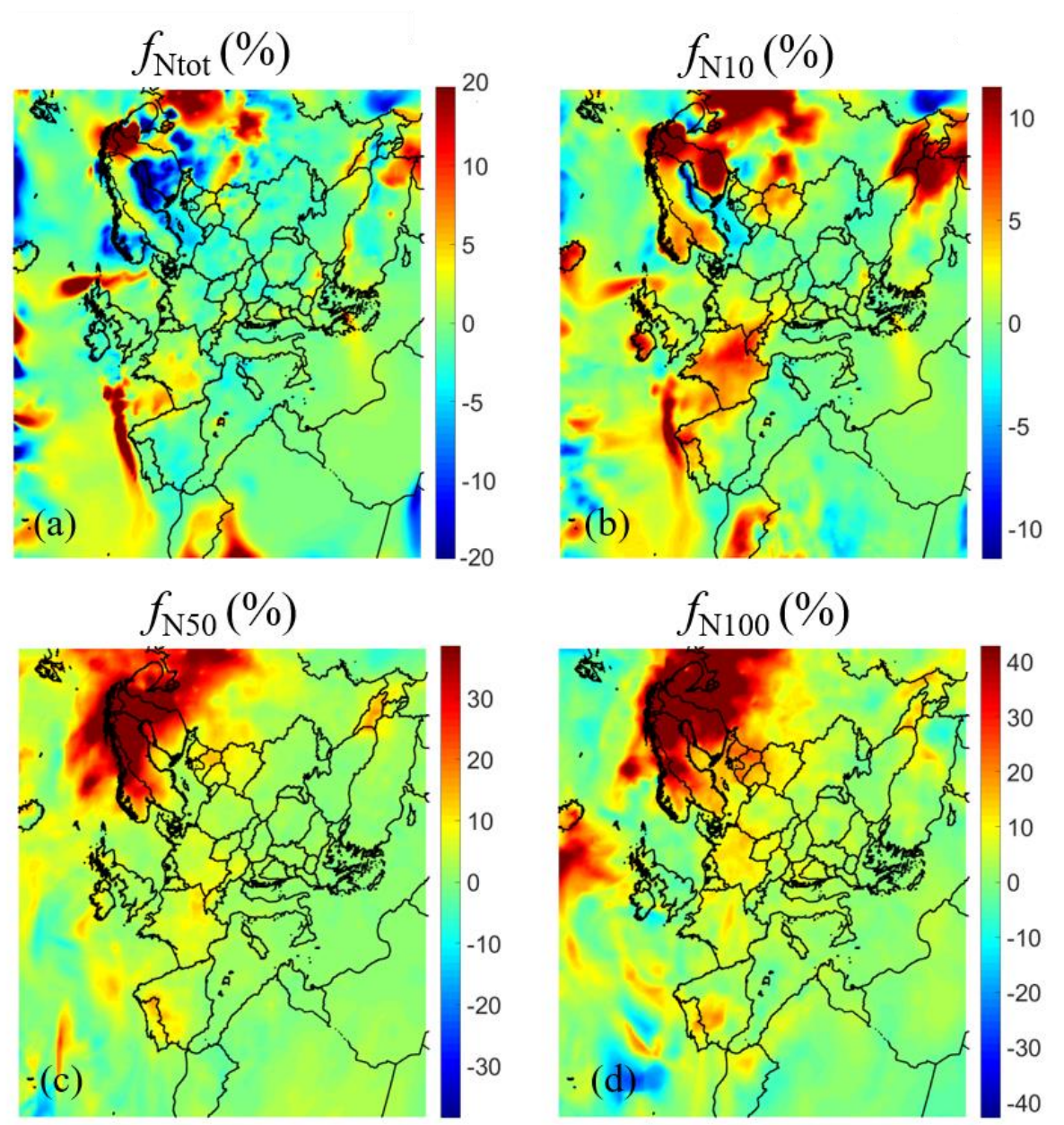

Figure 4: Average ground level fractional increase $\left(f_{N x}\right)$ of number concentration due to the condensation of ELVOCs for: (a) all particles $\left(f_{N t o t}\right)$; (b) particles above $10 \mathrm{~nm}\left(f_{N 10}\right)$; (c) above 50 $\mathrm{nm}\left(f_{N 50)}\right)$ and $(\mathrm{d})$ above $100 \mathrm{~nm}\left(f_{N 100}\right)$. Different scales are used. 

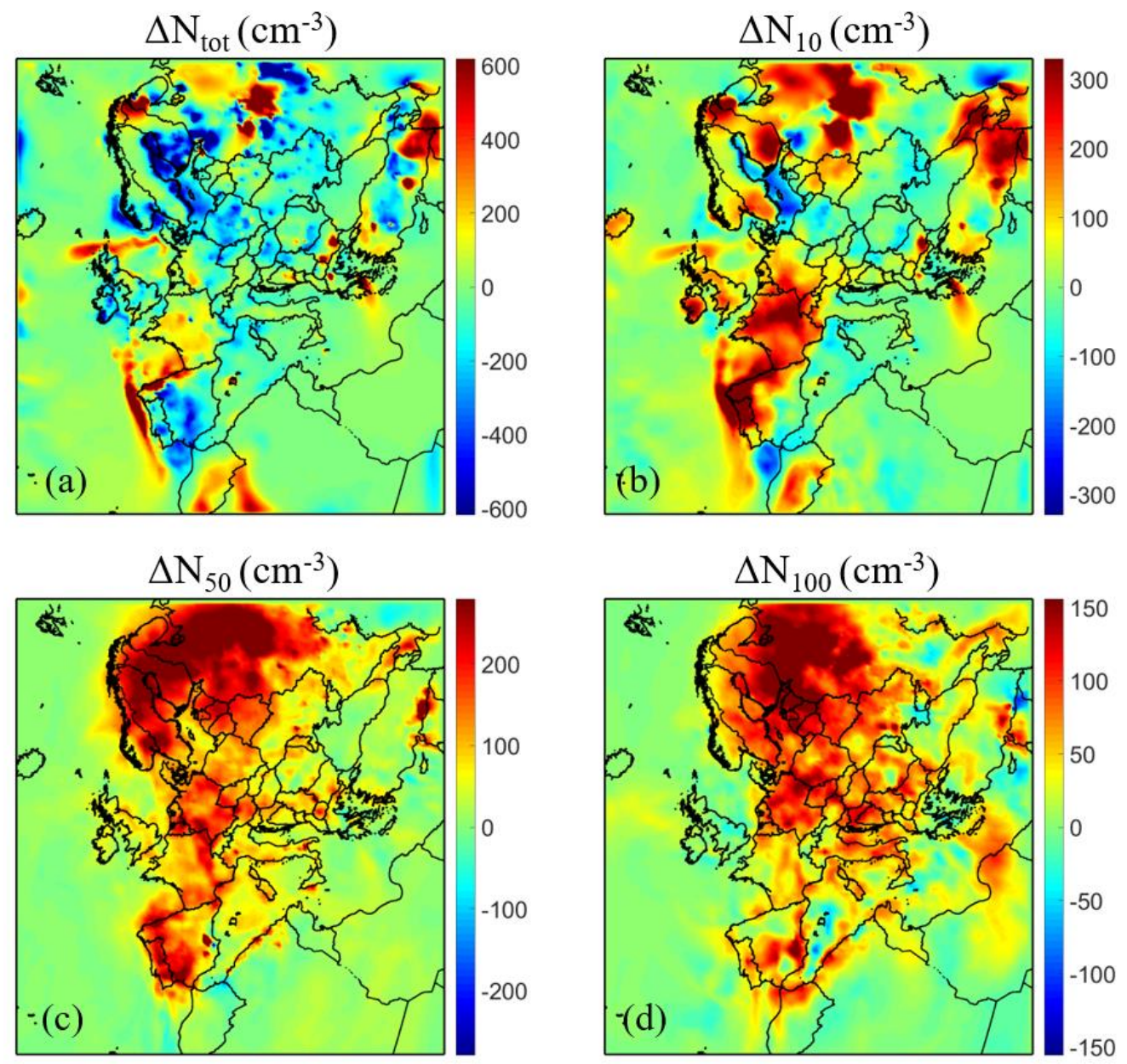

879 

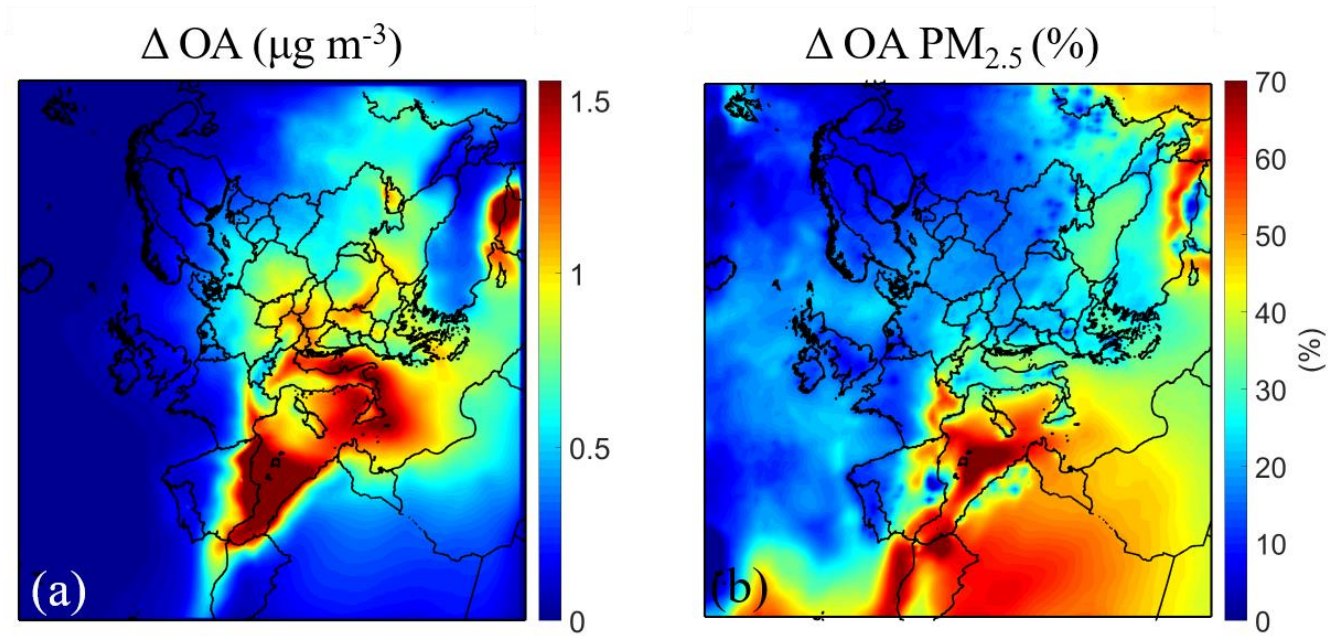

888

Figure 6: Ground level average (a) increase of $\mathrm{PM}_{2.5}$ mass concentration of organics aerosol (in $\mu \mathrm{g} \mathrm{m}^{-3}$ ) and (b) fractional increase of $\mathrm{PM}_{2.5}$ mass concentration of organics aerosol (\%) due to the addition of IVOCs emissions of semi-volatility organic aging, predicted during 5 June -8 July. Different scales are used.

893

894

895

896

897

898

899

900

901

902

903

904 

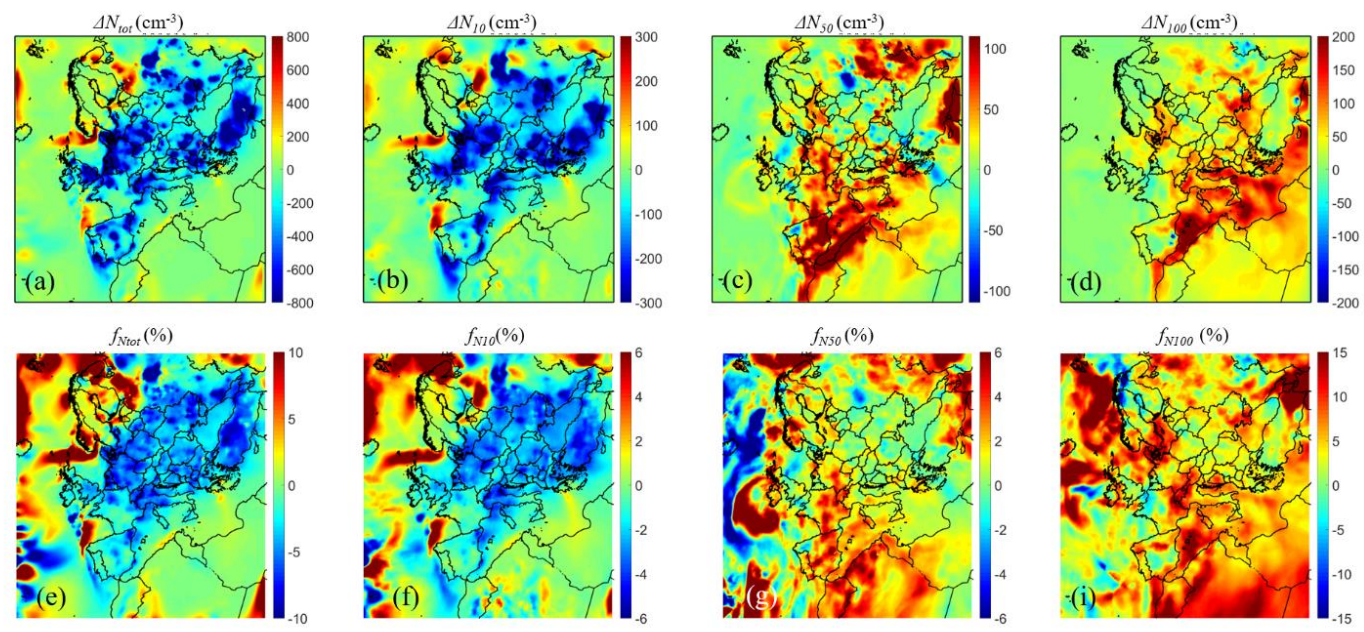

905

906 Figure 7: Ground level increase of number concentration (in $\left.\mathrm{cm}^{-3}\right)(\mathrm{a}-\mathrm{d})$ and fractional increase $907\left(f_{\mathrm{Nx}}\right)$ of number concentration (e-i) due to the addition of IVOCs emissions and aging reactions, 908 predicted during 5 June - 8 July 2012 for: (a, e) all particles $\left(N_{t o t}\right)$; and particles above (b, f) $10 \mathrm{~nm}$ 909 $\left(N_{10}\right) ;(\mathrm{c}, \mathrm{g}) 50 \mathrm{~nm}\left(N_{50}\right)$; and $(\mathrm{d}, \mathrm{i}) 100 \mathrm{~nm}\left(N_{100}\right)$. Different scales are used.

910

911 

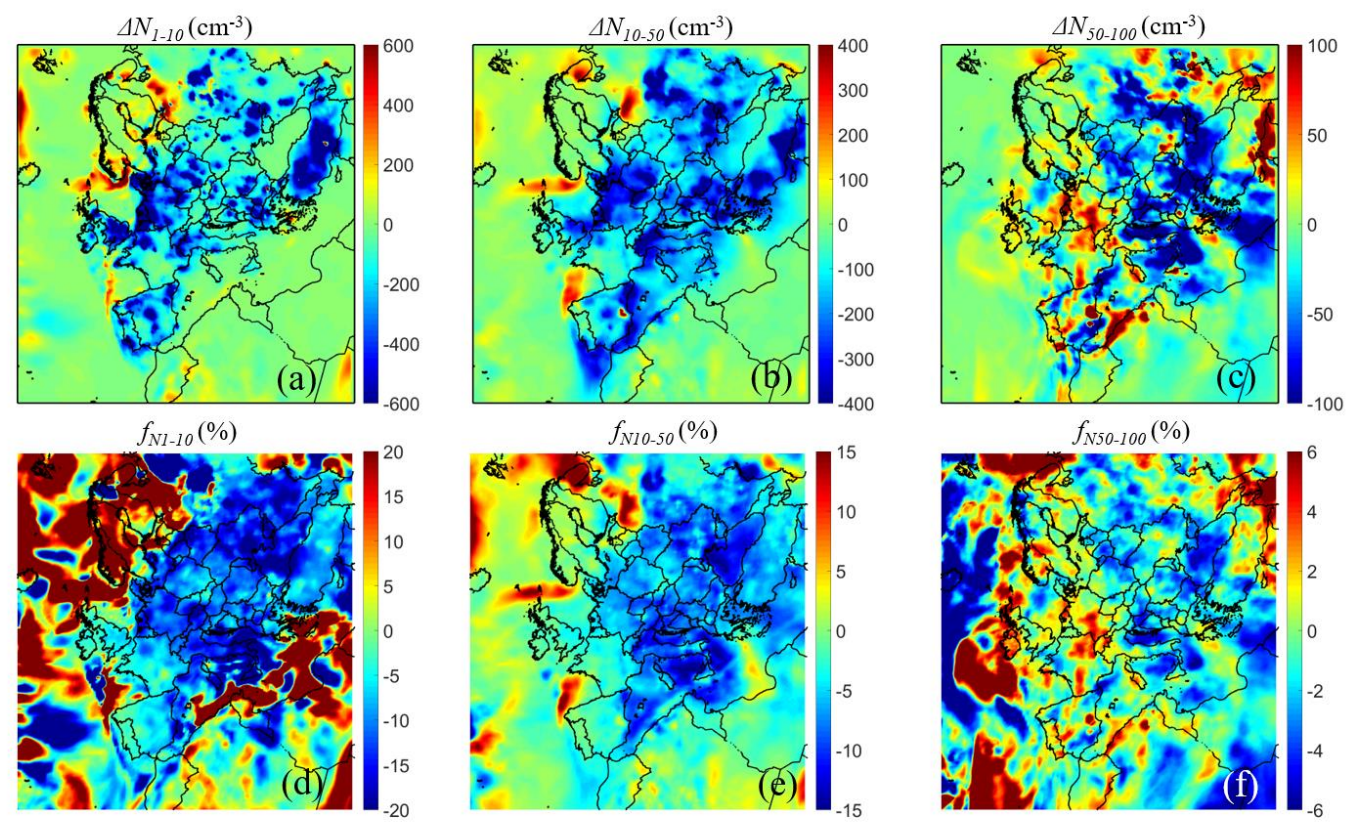

913 Figure 8: Ground level average increase of number concentration (in $\left.\mathrm{cm}^{-3}\right)(\mathrm{a}-\mathrm{b}-\mathrm{c})$ and fractional

914 increase $\left(f_{\mathrm{Nx}}\right)$ of number concentration (d-e-f) due to the addition of IVOCs emissions predicted

915 during 5 June - 8 July 2012 for: (a, d) particles between $0.8 \mathrm{~nm}$ and $10 \mathrm{~nm}\left(N_{1-10}\right)$; (b, e) particles

916 between $10 \mathrm{~nm}$ and $50 \mathrm{~nm}\left(N_{10-50}\right)$ and $(\mathrm{c}, \mathrm{f})$ particles between $50 \mathrm{~nm}$ and $100 \mathrm{~nm}\left(N_{50-100}\right)$.

917 Different scales are used. 